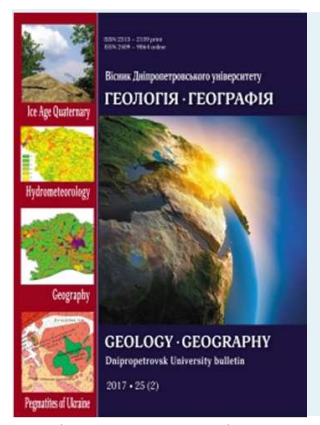

Geology $\bullet$ Geography Dnipro university bulletin

Journal home page: geology-dnu-dp.ua
ISSN 2313-2159 (print) ISSN 2409-9864(online)

Dniprop. Univer.bulletin. Geology, geography., $25(2), 3-22$. doi: $10.15421 / 111716$

Dniprop. Univer. bulletin, Geology, geography., 25(2), 3-22.

\title{
Целевая геолого-промышленная оценка Тереблянской солянокупольной структуры (Закарпатье)
}

\section{Л.П. Босевская}

Украинский научно-исследовательский институт соляной промышленности, Бахмут, Украина, e-mail:bosslara@gmail.com

Received 20 September 2017

Received in revised form 16 October 2017

Accepted 10 November 2017
Резюме. В настоящее время Тереблянская соляная структура рассматривается на различных уровнях как один из геологических объектов для восстановления соляной промышленности Закарпатья. Месторождение было детально разведано в середине прошлого века, однако до настоящего времени промышленное значение месторождения оставалось неопределенным. В работе впервые дана предварительная геолого-промышленная оценка соляного массива по результатам специализированной целевой оценки, основанной на инновационных методологических подходах к изучению свойств среды соляных массивов. Основным методическим приемом выполнения геолого-промышленной оценки явилась экспертная гармонизация фактических геологических данных разных лет с современными теоретическими подходами к оценке промышленных характеристик соляных толщ в авторской интерпретации. Исследования соляного массива выполнены с учетом понятия «функциональная оценка», включающего определение всех свойств пород соляного массива (функциональных), определяющих возможность его промышленного использования, - сырьевая ценность и принципиальная пригодность для техногенного вмешательства. Методологические принципы определения функциональных характеристик базировались на результатах структурно-литологического моделирования. Выполнена оценка современного номенклатурного состояния запасов каменной соли и разработаны рекомендации по подготовке запасов к использованию. В результате выполненной геолого-промышленной оценки определены возможные направления использования соляной структуры и обозначены перспективные участки для создания эксплуатационных объектов по направлениям с учетом комплекса эколого-геологических и технико-экономических критериев. Предложены варианты инвестиционных решений.

Ключевые слова: соляная порода, соляной диапир, функииональные свойства, структурно-литологическая модель, использование соляных толщ, выбор благоприятных участков

\section{Target-oriented geological industrial assessment of Tereblya salt dome structure (Transcar- pathia)}

\section{L.P. Bosevska}

Ukrainian Salt Research Institute, Bakhmut, Ukraine, e-mail: bosslara@gmail.com

Abstract. Tereblya salt structure is under consideration at different levels as one of geological objects for Transcarpathian salt industry recovery after emergency reduction of activities of the single salt-producing enterprise of the region in Solotvyno. Despite fulfilled detailed exploration of the Tereblya rock salt deposit towards the middle of the last century, its commercial significance had been staying indefinite until quite recently. This paper first presents the preliminary geological industrial assessment of the Tereblya salt massive by the results of specialized target oriented evaluation based on innovative methodological approaches to the study of salt massifs properties as objects of human made intervention. The basic methodical procedures of the geological industrial assessment performing are reinterpretation and expert harmonization of actual geological deposit data of various professional levels from different years and modern theoretical approaches to assessing of salt strata industrial characteristics, taking into account the established pattern of interconditionality of structural-lithological types of salt rocks and their operational and technological characteristics. Under rock salt research process, concept "functional evaluation" is used. It means finding of all properties of salt massive rock (functional) determining the possibility and expediency of its use for the creation of underground facilities for various purposes, namely raw material value and principal suitability for human-made intervention ensuring the minimization of environmental risks and protection of salt resources. Acknowledged methodological principles of target-oriented investigations of salt massifs environment by structural-lithological modeling have been used to identify spatial location of structural elements with different functional properties in the salt massif volume. Moreover the nomenclative assessment of modern rock salt reserves status has been 
accomplished as well as recommendations for reserves preparing to use have been developed. As a result of fulfilled geological industrial assessment the feasible uses of the salt structure have been indicated, promising sites for creation of exploration objects -by directions with an allowance for ecological-geological and techno-economic criteria for selection of favorable sites have been pointed, the options for investment decisions have been proposed. Furthermore, the minimum required complex of additional geologicaltechnological testing of rock salt has been emphasized to make correct investment decisions and develop a detailed geological and economic assessment of this deposit.

Keywords: rock salt, salt diapir, functional properties, structural and lithological pattern, salt strata using, favourable site selection

Введение. Актуальность проблемы и постановка задачи. После потери соляного производства в Закарпатье и прекращения функционирования уникальных подземных спелеосанаториев вследствие развития чрезвычайной экологической ситуации на территории Солотвинского месторождения каменной соли, приведшей к стремительному затоплению соляных рудников и полной деградации земной поверхности в зоне влияния горных работ (Bosevska, 2011), в качестве одного из основных альтернативных вариантов восстановления соляной промышленности и спелеотерапии в Закарпатье рассматривается Тереблянская соляная структура. Данный вопрос в течение нескольких лет обговаривается на разных уровнях (от уровня частных инвесторов до уровня государственных структур) с различных позиций, однако до настоящего времени промышленное значение Тереблянской соляной структуры остается неопределенным.

Общее геологическое строение месторождения освещают результаты геологической (И. Б. Плешаков), гравиметрической (Л. Е. Фильштинский) съемок и сейсморазведочных работ (3. С. Герцик, Г. П. Пенцак), выполненных после присоединения Закарпатья к Украине (после 1945 г.). Из архивных данных доукраинского периода особый интерес могут представлять сведения о существовании на месторождении древних шахт, однако такие данные в советских архивах не сохранились, поскольку территория в период функционирования шахт принадлежала Австро-Венгрии, а позже, с 1918 г., Чехословакии. Более детальное изучение структуры проводилось в ходе выполнения серии оценочных и структурно-поисковых работ в Закарпатье в период 1946 - 1970 годов. Результаты работ, включающие структурные и литологические особенности соляного массива, представлены в отчетах А. А. Иванова и С. М. Кореневского (1946 - 1948, 1966), М. М. Белоусова (1951), В. М. Щербы (1964, 1966 и 1968), А. А. Матвеевой (1965, 1970). Научное описание структуры приведено в работах В. И. Китыка (1958), С. М. Кореневского (1954 - 1956), М. И. Петрашкевича (1967), В. Н. Утробина (1955), А. М. Бокуна (1981) и др. В работе А. М. Бокуна (Bokun, 1981) детально исследованы механизм и факто- ры образования соляных структур в пределах Солотвинской впадины Карпатского внутреннего прогиба, в том числе и Тереблянского диапи$\mathrm{pa}$, с позиций тектонофизики путем моделирования на аналоговых материалах.

Детальная разведка месторождения с подсчетом запасов до глубины 500 м была выполнена в 1956 - 1957 годы (И. Н. Васильев, 1962) с целью подготовки базы хлоридно-натриевого сырья для развития химической промышленности Закарпатья (рассматривалось хлорщелочное производство и производство кальцинированной соды). В 1964 - 1965 годах были проведены дополнительные разведочные работы, включающие геофизические исследования для уточнения положения контуров соляного тела и качественных показателей каменной соли (А. И. Иванченко, 1967). К разработке кондиций для подсчета запасов был привлечен Всесоюзный научно-исследовательский институт галургии (ВНИИГ, Ленинград, 1970), однако последний квалифицировал месторождение как непригодное для разработки ввиду особенностей внутреннего строения и наличия повсеместного развития зон брекчирования, которые «по физико-механическим свойствам являются водопроницаемыми и геомеханически неустойчивыми». Таким образом, запасы Тереблянского месторождения до последнего времени (до 2017 г.) не были включены в Государственный баланс запасов полезных ископаемых.

Однако созданная за последние три десятилетия современная теоретическая база по исследованию свойств соляных массивов (Jeremic, 1994; Barjah, 1996; Shekhunova, 2001; Chabanovich, 2008; Roy, 2008; Hutorskoj, 2010; Khrushchov, 2010; Nazary et al, 2012), значительный объем новой геологической информации по осадочному комплексу Карпатского внутреннего прогиба (Andrieieva-Hryhorovych, 2009), в том числе баденской соленосной формации, к которой принадлежит Тереблянская структура (Bosevska, 2013), а также накопленный опыт эксплуатации Солотвинского месторождения предостерегают от категоричности выводов о непригодности данной структуры для промышленного использования и ввиду возобновленного промышленного интереса к ней требуют пол- 
ной переинтерпретации имеющейся базы данных.

Поэтому в контексте рассмотрения Тереблянской соляной структуры в качестве нового объекта использования соляных ресурсов Закарпатского региона представление ее целевой геолого-промышленной оценки является весьма актуальным. Выполненная оценка носит статус «предварительной» в связи с тем, что, несмотря на значительный объем проведенных разведочных работ, геологическая изученность месторождения как потенциального объекта эксплуатации может быть оценена только как средняя из-за полного отсутствия данных о технологических и физико-механических свойствах пород соляного массива.

Целью данной работы является представление предварительной целевой геологопромышленной оценки Тереблянской солянокупольной структуры на основе гармонизации фактических геологических данных разных лет и инновационных методологических подходов к целевой оценке соляных толщ для определения возможности его разноцелевого использования и определения перспективных участков создания подземных объектов.

Для достижения цели выполнены следующие задачи: 1) обобщение научных и фактических геологических материалов по Тереблянской структуре с учетом новейших данных об особенностях геологического строения Солотвинской впадины Карпатского внутреннего прогиба; 2) оценка современного номенклатурного состояния запасов каменной соли Тереблянского месторождения; 3) целевая оценка Тереблянской структуры на основе интерпретации ее структурно-литологической модели с целью определения участков, принципиально пригодных для техногенного вмешательства; 4) определение возможных направлений использования соляной структуры для добычи каменной соли и для целей, не связанных с эксплуатацией соляных ресурсов; 5) выбор благоприятных участков для подземного строительства по направлениям; 6) обозначение перспектив использования соляной структуры и разработка вариантов инвестиционных решений.

Материал, методология и методы исследований. Фактографической основой выполнения целевых исследований послужили колонки скважин детальной разведки Тереблянской структуры, а также новейшие данные по геологии и тектонике осадочного комплекса Карпатского внутреннего прогиба (2008 - 2009), результаты съемочного, поискового и структурнопоискового глубокого бурения, вскрывшего соляное тело на всю мощность. Всего на место- рождении пройдено более 30 поисковых и геологоразведочных скважин, в том числе около 20 скважин - с полным отбором керна.

Принципиальная геолого-промышленная оценка Тереблянского диапира выполнена с использованием апробированных инновационных методологических подходов к оценке свойств пород соляных толщ и установления их пригодности для использования в различных целях. Методология исследования соляных толщ с указанной целью заложена в работах Д. П. Хрущева и др. (Looff, 1998; Chabanovich, 2008; Khrushchov, 2009 - 2010, 2016).

Процедура выполнения геологопромышленной оценки производится в следующей последовательности: 1) целевая (функциональная) оценка соляной среды для установления благоприятных участков, принципиально пригодных для создания промышленных объектов различных типов по экологогеологическому критерию; 2) оценка геологических параметров, которые могут влиять на выбор участков и горно-геологические условия эксплуатации объектов; 3) установление соответствия геологических параметров выделенных перспективных участков техническим требованиям к созданию объектов различного типа с окончательным выбором рекомендуемых участков для подземного строительства.

Целевая оценка проводится с учетом понятия «функциональные свойства», подразумевающие определение всех свойств пород соляного массива (функциональных), действенных с точки зрения его использования и охраны, - сырьевая ценность и пригодность для экологически обеспеченного техногенного вмешательства. Сырьевая ценность определяется действующими стандартами на пищевую каменную соль и соль для промышленной переработки, техническими требованиями к хлориднонатриевому сырью в виде рассолов, получаемых при искусственном выщелачивании, технологическими свойствами каменной соли, обеспечивающими целесообразность ее использования по требуемым направлениям. Пригодность соляного массива (или отдельных участков) для техногенного вмешательства оценивается по следующим основным критериям: защищенность соляного массива (внешняя и внутренняя) по отношению к существующим или потенциальным источникам проникновения агрессивных подземных вод, провоцирующих развитие карста; достаточные прочностные характеристики соляных пород, позволяющие обеспечить длительную механическую устойчивость техногенно-геологической системы, создаваемой, как принято в мировой практике, без крепления. 
Внутренняя защищенность участка соляного массива, определяемая барьерными (фильтрационными) свойствами самих соляных пород, является главенствующей характеристикой для обеспечения экологической безопасности. Принципиальная оценка защищенности осуществляется по пятигрупповой системе качественной оценки: очень высокая, высокая, удовлетворительная, неудовлетворительная, катастрофическая. Раскрытие участков с катастрофическим и неудовлетворительным уровнем внутренней защищенности представляет собой одну из главных причин высокого экологического риска при техногенном вмешательстве в соляные толщи, поскольку приводит к развитию масштабных нарушений геологической среды со сложными экологическими последствиями (Khrushchov, 2009). К прочностным характеристикам соляных пород предъявляются значительно меньшие требования, поскольку механическая устойчивость созданной системы подземных полостей может регулироваться научно обоснованным выбором параметров системы разработки. Неприемлемыми участками по геомеханическим свойствам являются только объемы соляного массива с устойчиво сниженными показателями прочности (исходя из опыта эксплуатации соляных толщ, это показатели прочности на одноосное сжатие ниже 10 МПа). Обычно такие породы имеют высокую пористость и, соответственно, повышенные фильтрационные параметры, то есть низкую внутреннюю защищенность (Bosevska, 2010).

Исходя из общепризнанных теоретических представлений относительно взаимозависимости структурно-литологических особенностей и инженерно-геологических характеристик соляных толщ, целевая оценка соляного массива проводится согласно общепризнанному методологическому принципу - по результатам структурно-литологического моделирования (Khrushchov, 2002; Chabanovich, 2008). При этом методология выполнения целевой оценки заключается в определении и объемной геометризации положения структурных элементов с разными функциональными свойствами в конечном объеме массива, подлежащего исследованию. Отдельным методическим приемом структуризации соляного массива является установление структурно-литологических типов (СЛТ) пород соляного массива, которые отвечают определенному функциональному типу.

При выделении СЛТ пород Тереблянского соляного массива общие методологические принципы были адаптированы для баденской соленосной формации Закарпатья, к которой принадлежат более 20 соляных диапировых структур, в том числе Тереблянская и Солотвинская (Bosevska, 2013).

Выделение СЛТ производилось путем переинтерпретации фактических данных бурения скважин детальной разведки и экспертной гармонизации материалов разных лет и различного профессионального уровня с авторскими принципами в соответствии с общими методическими приемами литологической структуризации соляных толщ. В качестве основных характеристик использовались следующие: структурнотекстурные особенности, визуальные признаки (цвет, степень связанности зерен, прочность), результаты поинтервальных лабораторных определений вещественного состава (химического, минерального) и некоторых технологических параметров. Определение структурнолитологических типов по отдельным интервалам опорных разрезов Тереблянской структуры было затруднено в связи с весьма скудным описанием структурных и текстурных особенностей породы, а также полным отсутствием данных по физико-механическим свойствам пород (при выполнении разведочных работ в середине прошлого столетия не предусматривалось выполнение технологических и геомеханических испытаний кернового материала). В этих случаях использовались такие испытанные методы оценки функциональных свойств соляных пород как метод аналогий (с использованием огромного пакета данных по Солотвинскому месторождению) (Bosevska, 2011) и метод оперативной оценки свойств соляных пород - учет выхода керна при бурении скважин (\%). При соблюдении технологии бурения последний достаточно точно отображает пустотность породы и степень ее сцементированности, которые, в свою очередь, определяют главные функциональные свойства соляных пород - барьерные и прочностные. Для соляных пород высоких и очень высоких функциональных свойств выход керна всегда равен $100 \%$, для удовлетворительных - колеблется около 90 - $100 \%$, а для соляных пород, непригодных для использования по функциональным свойствам, - снижается до 70 $\%$ и ниже.

1. Общая геологическая характеристика объекта исследований в современной интерпретации. Тереблянское месторождение каменной соли административно расположено в южной части Закарпатской обл. Украины, в с. Теребля Тячевского района, в 20 км к северу от г. Тячев и в 10 км от ближайшей железнодорожной станции Буштыно.

В геоморфологическом отношении территория месторождения представляет собой ровную, в значительной степени заболоченную 
территорию, расположенную в пределах правой первой надпойменной террасы горной реки Теребля, которая огибает соляную структуру с востока (рис. 1, 2). Верхняя часть соляной структуры ранее разрабатывалась двумя шахтами, сведения о которых предельно скудны. Извест-

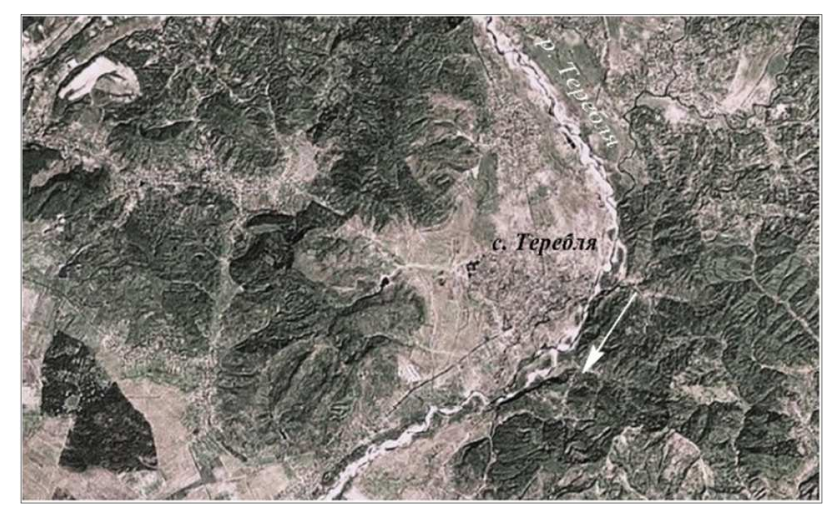

Рис. 1. Аэрофотоснимок территории

Тереблянского месторождения каменной соли

В геолого-структурном отношении Тереблянская структура приурочена к наиболее мощной полосе развития диапиризма баденской соленосной формации Солотвинской впадины Данилово-Тереблянской брахиантиклинали, тектонически связанной с центральным продольным Данилово-Тереблянским глубинным разломом. При этом Тереблянский диапир является одним из четырех открытых ядер протыкания (наряду с Боронявским, Даниловским и Александровским), осложняющих структуру более высокого порядка. В центральной части ядра протыкания соляная толща выходит на поверхность (под маломощные четвертичные отложения).

Стратиграфически соленосные отложения представлены тереблянской свитой, расположенной в нижних частях разреза неогеновой молассы и согласно перекрытой мощной вулканогенно-терригенной монотонно-слоистой толщей солотвинской свиты.

Интенсивное развитие диапиризма в районе Теребли связано с зоной пересечения продольного Данилово-Тереблянского разлома поперечным, Великоугольским, что обусловило сложный механизм образования диапира (Bokun, 1981), и, соответственно, очень сложную морфологическую конфигурацию структуры на этом участке (рис. 3).

Внешнее строение соляного тела. Общая морфология Тереблянской структуры соответствует форме пластичного тела, которое в условиях сложной геодинамической обстановки подвергается воздействию разнонаправленных сил (Looff \& Looff, 1998; Bosevska, 2013). По геофизическим данным, проекция соляного тела но, что шахты эксплуатировали верхнюю часть соляной структуры, приближенную к поверхности, в период от Средневековья до начала XX столетия, когда территория принадлежала Австро-Венгрии.

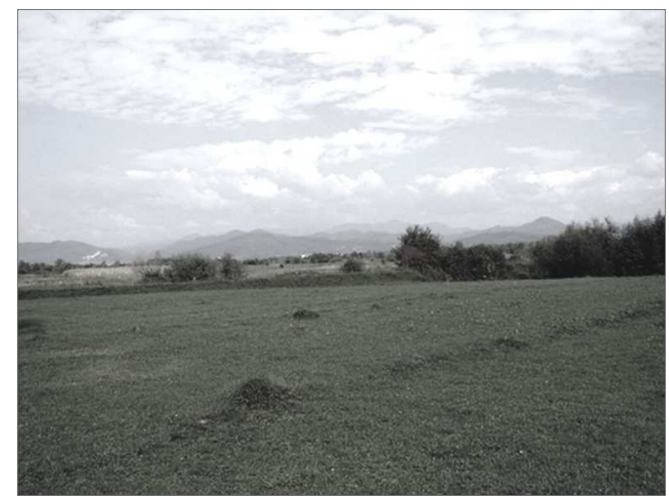

Рис. 2. Геоморфологическое отображение Тереблянской структуры

на земную поверхность имеет форму усложненного овала с размерами $1,7 \times 2,2$ км. На поверхности купола имеет место мульдообразный прогиб, гипсометрия подошвы которого не установлена. Нижняя граница соляной толщи находится на глубинах $900-1500$ м. В верхней части форма диапира усложнена выступами причудливой формы и пережимами, вследствие чего резко изменяются форма и площадь горизонтальных срезов на различных уровнях и в разных геологических профилях. Линейные сечения диапира на различных уровнях до глубины 250 - 300 м изменяются от 200 до 1300 м, поэтому приведенные данные о размерах структуры достаточно условны - они характеризуют размеры проекций выступов боковой поверхности соляного тела на земную поверхность. Полная вскрытая мощность соляной толщи в центральной части структуры - до 1300 м.

В поперечном разрезе структура имеет выраженно асимметричное строение: ядро соляного тела погружается в северо-северовосточном направлении, при этом северное крыло падает под углом $50-70^{\circ}$, а южное запрокинуто. Из-за чрезвычайно сложных морфологических очертаний структуры А. Н. Бокун давал противоположную информацию, но приведенный нами характер морфологии соляного тела подтвержден специальными геофизическими исследованиями, а также результатами моделирования, выполненного в рамках данной работы по результатам авторской интерпретации совокупности всех геологических данных разных лет. Выполаживание боковых поверхностей диапира с постепенным переходом к пластовому залеганию происходит на глубинах бо- 
лее 700 м. Боковая поверхность соляного тела на контакте с вмещающей толщей значительно усложнена тектоническими нарушениями, при этом наибольшему брекчированию подвержено запрокинутое юго-западное крыло соляного тела, приближенное к глубинному разлому (рис. 4).

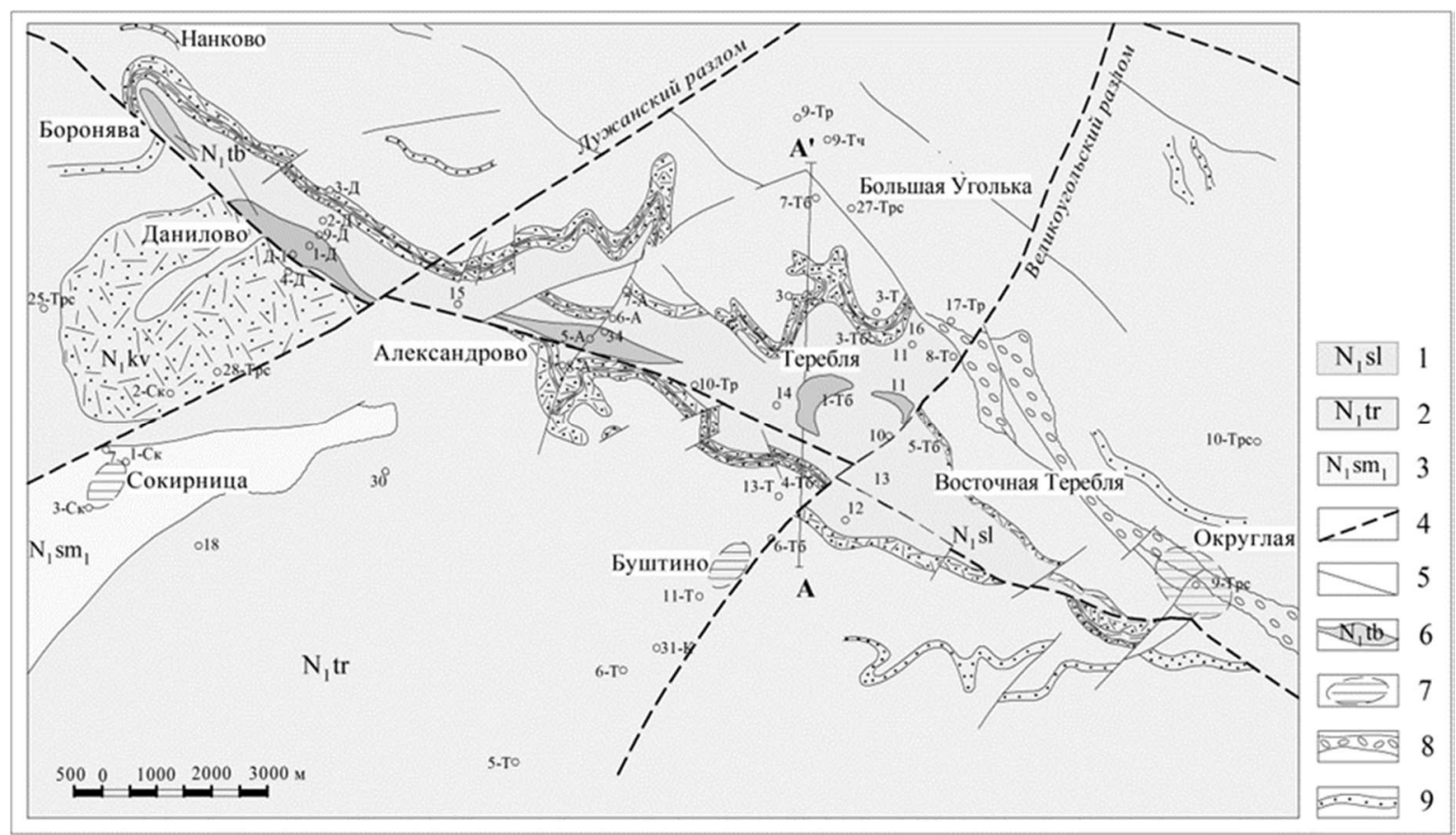

Рис. 3. Геологическая карта центральной части Солотвинской впадины:

1 - солотвинская свита, 2 - тересвинская свита; 3 - нерасчлененные отложения сармата; 4 - унаследованные глубинные разломы; 5 - разломы в пределах неогеновой молассы; 6 - открытые соляные диапиры; 7 - диапироиды, не выходящие к поверхности; 8 - маркирующие слои конгломератов; 9 - маркирующие слои песчаника

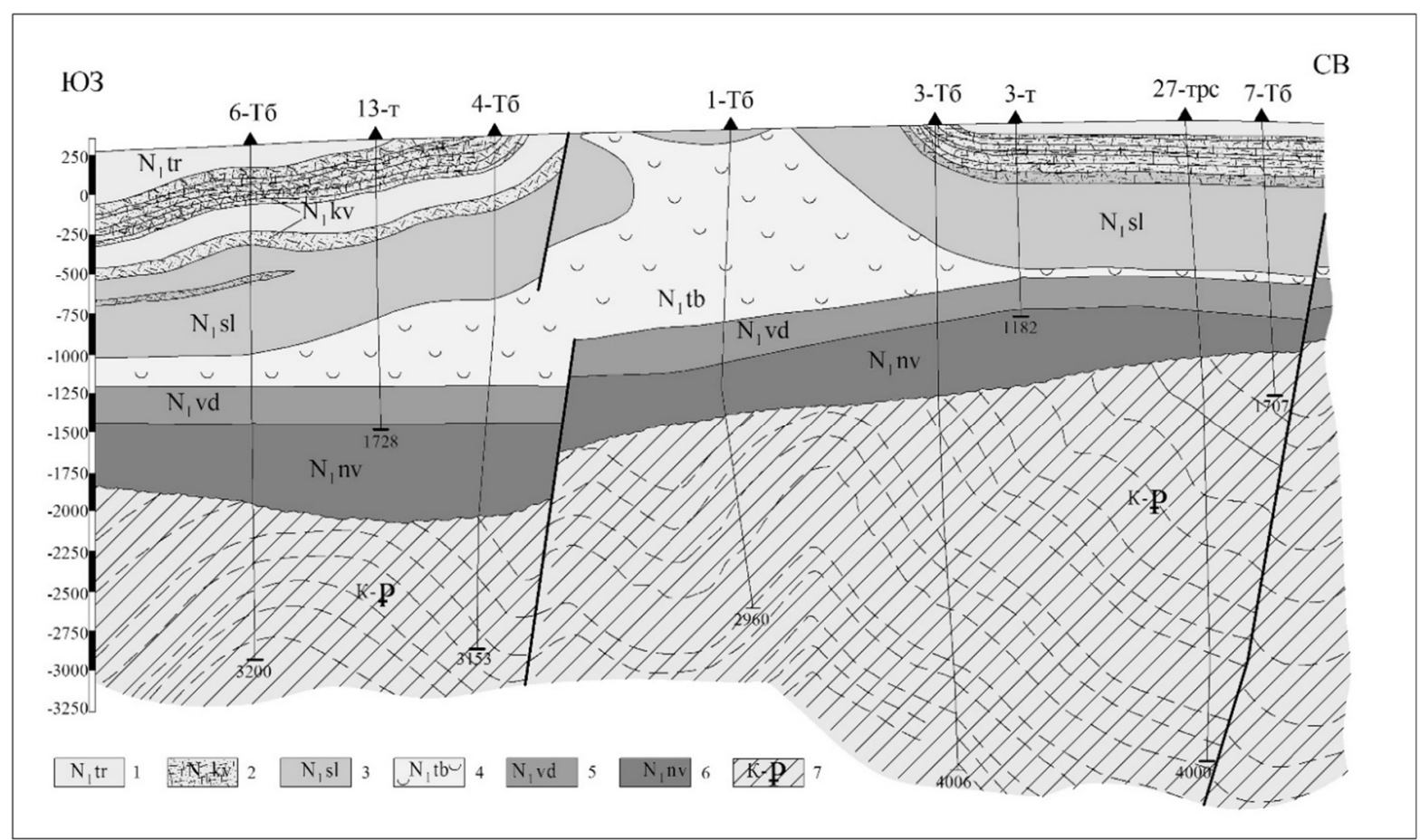

Рис. 4. Поперечный геологический профиль центральной части Тереблянской структуры по линии $\mathrm{A}-\mathrm{A}^{\prime}$ (по материалам С. М. Кореневского, В. М. Щербы, А. М. Бокуна и А. Андреевой-Григорович)

1 - тересвинская свита (аргиллиты, алевролиты, песчаники); 2 - региональный маркирующий горизонт ковачских туфов; 3 - солотвинская свита (аргиллиты, песчаники с прослоями риолитовых туфов, туффитов); 4 - тереблянская соленосная свита; 5 - водицкая свита (аргиллиты, алевролиты, туффиты); 6 - новоселицкая свита (осадочно-вулканогенная толща: зеленые туфы риолито-дацитов с прослоями туффитов, аргиллитов, туфопесчаников, конгломератов); 7 - мел-палеогеновый кристаллический фундамент (мергели, известняки, аргиллиты, алевролиты) 
Вмещает соляное тело относительно однородная сероцветная флишеподобная вулканогенно-осадочная толща пород солотвинской свиты, представленной глинами, известковистыми алевролитами, аргиллитами, глинистыми и песчанистыми известняками, мергелями, а также зеленоватыми туфами с подчиненным количеством известковых песчаников. Соляной диапир и вмещающая толща перекрыты сплошным маломощным четвертичным чехлом (до 50 - 70 м), представленным аллювиальными образованиями: галечником с валунами и примесью песка, песчанистых глин и гравия. К аллювиальным отложениям приурочен водоносный горизонт первой и второй надпойменных террас реки Теребля.

На участках выхода соляного тела под четвертичные отложения сформирован глинистый кепрок (от 2 до 10 м), который распространяется за контуры выхода соляного тела под обводненные надсолевые отложения в направлении движения грунтового потока (на юго-восток). Кепрок представлен вязкими, пластичными серыми глинами с включениями обломков серовато-белого ангидрита и гипса и в целом может по качественным характеристикам оцениваться как водоупор.

Внутреннее строение соляного тела отличается неравномерным чередованием слоев в различной степени загрязненной каменной соли и слоев соленосных и засолоненных терригенных пород, а также пород смешанного состава. Общее ориентирование слоистости приближенно отвечает залеганию боковой поверхности в соответствующем интервале глубин, то есть прослеживаются принципы субконцентрического стиля внутреннего строения. Литологический состав соляных пород отличается значительной пространственной изменчивостью даже в пределах одного слоя.

Соляная порода представлена преимущественно загрязненной и сильно загрязненной типичной галокинетической каменной солью. Состав примесей идентичен вещественному составу несоляных пород, характерных для всей баденской соленосной формации, - преимущественно глинистые включения, а также в меньшем количестве - ангидрит. Глинистый материал, представленный тонкодисперсными примесями, включениями угловатых обломков, а также крупных будин размером до 5-10 м, неравномерно распределен в соляной породе, определяя степень ее загрязнения, а также слагает отдельные структурные элементы соляной толщи более высоких порядков. Ангидрит встречается преимущественно в виде серовато-белых желваков размером около $5-10$ мм и тяготеет по распространению к прослоям, наиболее загрязненным глиной.

В целом количество несоляных компонентов значительно превышает таковое для Солотвинского месторождения, однако, в отличие от последнего, каменная соль Теребли отличается значительно большей плотностью при определенных интервалах загрязнения, что находит отображение в увеличении среднего показателя удельного веса до 2,2 г/ $\mathrm{cm}^{3}$. Вероятно, такое отличие связано с более высоким геодинамическим давлением, которому был подвержен Тереблянский соляной массив в процессе галокинеза.

Чистая белая или светло-серая каменная соль встречается очень редко, ее не выдержанные по простиранию прослои имеют мощность, не превышающую 5 м. Наиболее распространенной является каменная соль серого и темносерого цвета массивной или неяснослоистой макротекстуры. Резко преобладает каменная соль весьма крупнозернистой и гигантозернистой перекристаллизованной структуры с размером зерен до 15 мм. Средняя соленасыщенность соляных слоев тела составляет от 80 до $98 \%$.

Слои внутриформационных несоляных пород представляют собой почти исключительно соляно-глинистую породу (50 - 75 \% нерастворимого остатка (НО)), соленосные или засолоненные аргиллитоподобные глины (соответственно 75 - $90 \%$ и больше $90 \%$ НО). Слои засолоненных глин в значительной степени гидратизированы, имеют темно-серую окраску и часто включают маломощные прослои темносерых или синевато-серых карбонатных алевритистых глин, светло-серых алевролитов, а также массивных метаморфизованных плотных песчаников с карбонатным цементом.

Засолоненные и соленосные несоляные породы в объеме соляного массива составляют до $15 \%$, образуя пласты истинной мощностью от нескольких сантиметров до 60 м с преобладанием мощности $2-7$ м. Мощные глинистые пласты $(20-50$ м) представляют собой существенные элементы внутреннего строения соляного массива, разделяющие отдельные пачки соляной породы.

Слои несоляных пород по простиранию часто постепенно переходят в соляно-глинистые и глинисто-соляные брекчии, формирующиеся на участках внутренней складчатости и перегиба слоев в соответствии с направлением течения каменной соли. Степень брекчирования обусловлена интенсивностью тектонических дислокаций и первичными литологическими особенностями несоляных пород. Плотные аргил- 
литы в зоне дислокаций разбиваются на огромные угловатые будины размером от нескольких сантиметров до 15 см и больше, которые в процессе дальнейшего галокинеза цементируются каменной солью, имеющей волокнистую или зернистую структуру.

Закономерности формирования зон брекчирования соленосной толщи целиком аналогичны тем, которые были установлены ранее для Солотвинского купола (Bosevska, 2010), однако существенное отличие Тереблянской соляной толщи от массива Солотвино состоит в значительно большем количестве терригенных пород, в большей степени тектонических дислокаций, которым они были подвержены, и, соответственно, большей степени их брекчирования. Глинисто-соляная брекчия в объеме породы составляет $20 \%$ (без учета объемов брекчий преимущественно глинистого состава).

2. Качественная характеристика и современное состояние запасов каменной соли Тереблянского месторождения. Из-за существенного загрязнения каменной соли месторождения примесями и включениями несоляных пород сырьевая ценность месторождения невысокая. Средневзвешенное содержание основных компонентов в пределах разведанной части месторождения составляет: $\mathrm{NaCl}-88,75 \%, \mathrm{Ca}-$ $0,33 \%, \mathrm{Mg}-0,02 \% ; \mathrm{SO}_{4}-0,71 \% ; \mathrm{K}-0,014 \%$; $\mathrm{HO}-10,36 \%$. Усредненный химический состав каменной соли позволяет оценивать возможность подземной добычи шахтным способом только каменной соли II сорта для промышленной переработки (ДСТУ 4246:2003 «Сіль для промислового переробляння. Технічні умови»).

В соляном массиве имеют место отдельные прослои и слои снежно-белой чистой соли мощностью, обычно не превышающей 5 м (иногда - до 20 м и более), соответствующие по качеству пищевой соли (содержание $\mathrm{NaCl}-98,7-$ 99,9 \% (скв. 27-Д), на отдельных участках - 99,1 - 99,4\%,), однако принятые системы подземной разработки соляных месторождений подземным способом не позволяют рентабельно селективно извлекать полезное ископаемое из маломощных прослоев невыдержанной мощности.

Приведенные качественные характеристики соляного массива позволили изначально оценить месторождение только как источник хлоридно-натриевого сырья для химической промышленности, при этом извлечение полезного ископаемого предусматривалось геотехнологическим методом (методом подземного выщелачивания). С этой целью по результатам выполненных детальных разведок были подсчитаны и представлены на утверждение запасы по кат. $\mathrm{A}+\mathrm{B}+\mathrm{C}_{1}+\mathrm{C}_{2}$ в количестве 1,4 млрд т, однако подсчитанные запасы были квалифицированы как оперативные и не были утверждены ГКЗ из-за неполноты представленных материалов, отсутствия утвержденных кондиций, а также утраты актуальности утверждения запасов: отмены решения о создании химического производства в Закарпатье. В целом геологические запасы Тереблянского месторождения оцениваются в $4-5$ млрд т.

После возобновления интереса к Тереблянской структуре в $2014-2015$ гг. инициативно частной компанией ООО «Катион Инвест» выполнена предварительная геологоэкономическая оценка участка месторождения (ГЭО-2), выделенного в пределах ранее разведанной площади с учетом размещения поверхностных объектов инфраструктуры (рис. 5).

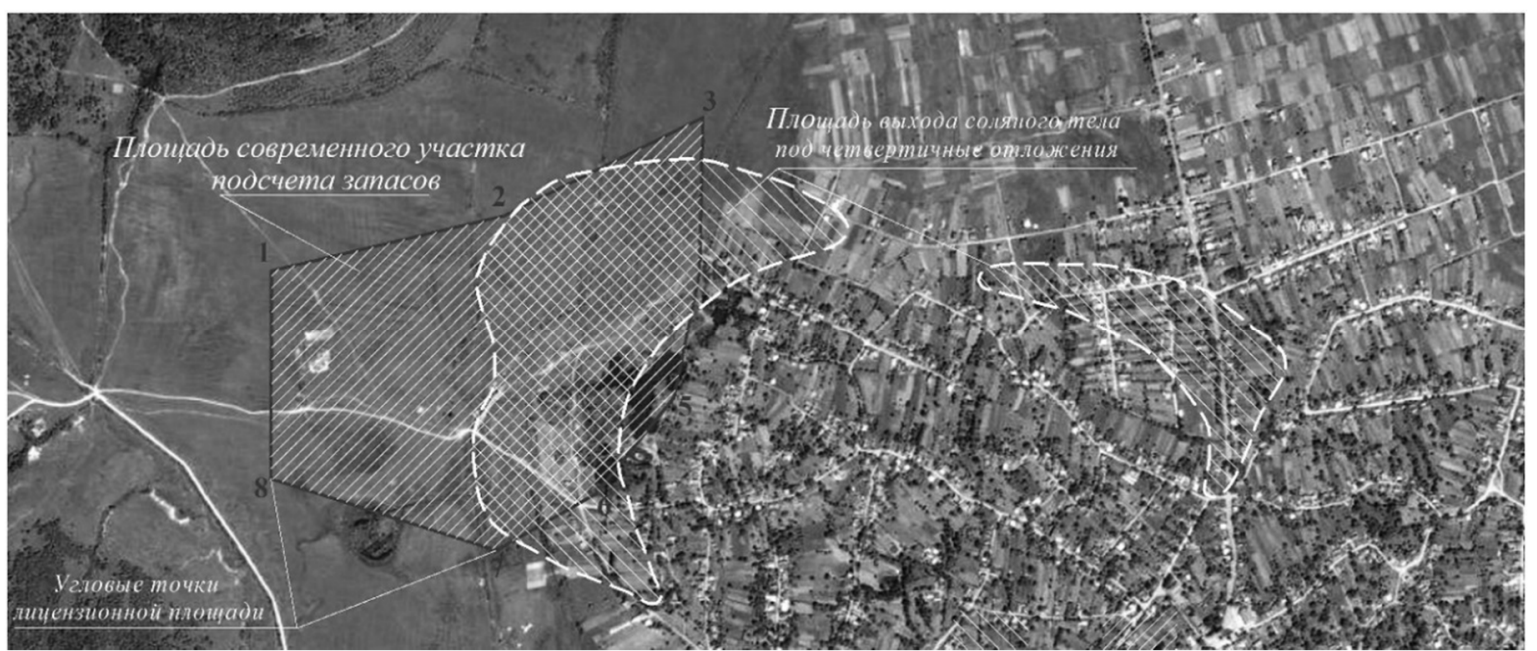

Рис. 5. Аэрофотоснимок территории Тереблянского месторождения с нанесением контуров современного подсчета запасов (площади разрешения на пользование недрами, Протокол № 6192 от 16.03.2017 г.) и контуров выхода соляного тела под четвертичные отложения 
Подсчет запасов выполнен по имеющимся архивным материалам детальных разведок до абс. отм. - 230 м (глубина 480 м). Выбранная площадь подсчета запасов ограничена с юга, запада и севера положением разведочных скважин и дополнительными точками, установленными с применением метода экстраполяции, а с востока - условной границей с застроенной частью села Теребля. Представленный участок месторождения Протоколом ГКЗ Украины № 3330 от 05.03.2017 г. признан подготовленным для дальнейшего геологического изучения, и запасы в количестве 565,9 млн т (кат. $\mathrm{C}_{1}+\mathrm{C}_{2}$ ) переданы на апробацию, включающую геологическое доизучение и опытно-промышленную разработку для добычи технической соли II сорта на условиях экономического риска. Из подсчитанной суммы запасов (по состоянию на 01.01.2015 г.) только 15,5 млн т утверждены как балансовые по кат. $\mathrm{C}_{1}$, при этом 550,4 млн т признаны запасами неопределенного промышленного значения (кат. $\mathrm{C}_{2}$ ).

3. Оценка перспективности Тереблянской структуры и выбор благоприятных участков для подземного строительства.

3.1. Целевая (функциональная) оценка Тереблянской структуры. Оценка перспективности соляной структуры и выбор перспективных участков для ее использования в различных целях осуществляется по эколого-геологическому и технико-экономическому критериям. Экологогеологический критерий подразумевает установление благоприятных участков с точки зрения экологической безопасности, прежде всего, обеспечения длительной механической устойчивости породного массива, содержащего пустотное пространство, и предотвращения развития крайне опасных карстовых процессов (Cooper, 2002; Gutirrez, 2008). Техникоэкономический критерий выражается в установлении соответствия геологических параметров выделенных перспективных участков месторождения определенным усредненным техническим (технологическим) требованиям, которые регулируются соответствующими нормативными документами для разных типов подземных объектов или экономической целесообразностью.

По эколого-геологическому критерию участки выбираются путем выполнения функциональной оценки пород соляного массива (Bosevska, 2010). Одной из основных функциональных характеристик для геологопромышленной оценки месторождений солей является защищенность соляной толщи и отдельных ее участков (по отношению к потенци- альным источникам пресных вод) (Khrushchov, 2009).

Внешняя природная зашищенность Тереблянской структуры определяется наличием напорно-безнапорного водоносного горизонта, приуроченного к четвертичным аллювиальным отложениям первой надпойменной террасы реки Теребля. Питание горизонта осуществляется за счет инфильтрации атмосферных осадков, вод второй надпойменной террасы, а также на отдельных участках - за счет перелива напорных вод спорадически развитого трещинного водоносного горизонта солотвинской свиты, приуроченного к зонам разломов. Обводненность отложений солотвинской свиты непрогнозируема, поскольку это типичный водоносный горизонт трещинного типа, развитый в зонах тектонических нарушений. Удельные дебиты вод составляют $0,1-0,4$ л/с, а напоры достигают $60-$ 70 м. Гидравлическая взаимосвязь вод трещинного горизонта солотвинской свиты с четвертичным водоносным горизонтом доказана.

Мощность аллювиального водоносного горизонта - от 3 до 25 м (редко - до 50 м). Уровень вод над центральной частью структуры приближен к земной поверхности и фиксируется на глубинах 0,5-2,5 м, при этом в северном направлении глубина зеркала четвертичных вод растет и может достигать 20 м. На участках, где аллювиальные отложения перекрыты глинами, воды напорные (напор до 13 м). Фильтрационные свойства четвертичных пород невысокие (коэффициенты фильтрации составляют 0,3 0,8 м/сут.). Водоносный горизонт имеет характерную выраженную вертикальную зональность: его нижние слои представляют собой рассольный горизонт. Движение подземных вод аллювиального водоносного горизонта направлено на юго-восток, к руслу реки Теребля.

Совокупный анализ внешнего строения и основных фильтрационных параметров надсолевых и боковых водоносных горизонтов показывает, что участки, заглубленные под надсолевую толщу на глубины $50-100$ м, имеют высокий или удовлетворительный уровень защищенности на удалении от зон разломов вмещающей толщи. Наиболее уязвима центральная часть структуры, контактирующая с четвертичным водоносным горизонтом. Ее защищенность определяется наличием маломощного глинистого кепрока, который в совокупности с рассольным горизонтом создает условия самозащиты соляного тела, представляя собой условный гидравлический барьер. Это позволяет с учетом фильтрационных показателей водоносного горизонта суммарный защитный потенциал верхней части соляного тела в природном состоянии 
условно оценить как удовлетворительный (третья группа по пятибалльной системе). Следует отметить также, что кепрок подвержен незначительным техногенным нарушениям из-за наличия старых шахт (в районе скв. 26, 27, 33), затопленных в результате прорыва аллювиальных вод с последующим образованием озер над ними.

Достаточно условная защищенность соляного массива подтверждается наличием процессов площадного выщелачивания, о чем свидетельствует химический тип вод природных источников в пойме p. Теребля, - хлоридный натриевый или сульфатно-хлоридный натриевый (генетические коэффициенты свидетельствуют о том, что это типичные воды выщелачивания каменной соли).

При удовлетворительном внешнем защитном потенциале промышленное использование месторождения, подразумевающее создание подземных объектов (полостей), возможно только в пределах участков с высокой внутренней защищенностью участков соляного массива.

Внутренняя защчищенность соляного массива определялась апробированным методологическим приемом путем установления в соляном массиве внутренних гидравлических барьеров и участков с повышенной потенциальной проницаемостью. Основными внутренними барьерами для Тереблянского массива являются выдержанные по мощности пласты глинистых пород и сама каменная соль с высокими функциональными свойствами.

Определение функциональных характеристик пород соляного массива и распределение их в объеме структуры было выполнено путем структурно-литологического моделирования, принципы которого для структур баденской соленосной формации изложены в предшествующих работах. Исходя из этого, функциональная оценка среды Тереблянского соляного массива для целевой геолого-промышленной оценки была сведена к установлению пространственной (объёмной) геометризации положения её структурных элементов с различными функциональными свойствами (Bosevska, 2013).

Для Тереблянской структуры выделено четыре основные группы структурнолитологических типов пород, принципиально определяющих их пригодность для экологически обеспеченного создания полостей внутри соляного массива любого назначения, а также зоны течения с неустойчивыми функциональными характеристиками. Выделенные группы СЛТ 1 и 2 представляют собой чистую или загрязнённую плотную каменную соль (от прозрачно-белой до темно-серой), отличающуюся относительно равномерным распределением микропримесей и включений несоляных пород с сохранением каркасной структуры каменной соли, а также высокой степенью цементации, что обеспечивает достаточные для подземного строительства барьерные свойства пород (низкая вероятность карста; предел прочности на одноосное сжатие $\left(\sigma_{c}\right)$ варьирует в пределах от 20 - 32 до 30 - 40 МПа и более). Принципиальное отличие между группами СЛТ 1 и 2 заключается в соленасыщенности как сырьевой характеристике (и, соответственно, содержании НО). Характерной отличительной особенностью группы СЛТ 3 является весьма неравномерное распределение примесей и включений в породе, что обуславливает значительную анизотропию свойств. Группу 4 составляет ослабленная слабо сцементированная соляная порода с признаками незавершённой перекристаллизации, часто - с открытой пористостью и наличием седиментационных рассолов в межзерновом пространстве. Показатели прочности такой породы обычно составляют 10 - 20 МПа и менее, а керн может представлять собой шлам.

Следует отметить, что по материалам детальной разведки (1967) достаточно сложно было установить зоны течения общепринятым литолого-петрографическим методом, в связи с чем эти зоны устанавливались по косвенным признакам - резкому уменьшению плотности и прочности соляной породы ориентированной структуры (флюидальной текстуры) на коротком интервале, отвечающем участкам повышения соленасыщенности, особенно на контактах с глинистыми слоями. Выявление зон течения показало, что их спорадическое распространение имеет место преимущественно в пределах слоёв слабозагрязненной каменной соли.

В процессе структурно-литологического моделирования выполнено расчленение 18 скважин детальной разведки по представленным группам СЛТ, которое составило базу данных для построения объемных аналоговых фрагментов СЛМ для участков, представляющих интерес, с использованием априорики. Изза сложного внешнего строения соляного тела, которое в значительной степени определяет и внутреннее строение диапира, а также однотипного вещественного состава, корреляция породно-слоистых элементов внутреннего строения диапира по имеющейся базе данных является задачей чрезвычайно сложной и часто неоднозначной. Главное маркирующее значение для установления внутреннего строения массива имеют мощные слои аргиллитоподобных глин. Крупные структурные элементы соляного мас- 
сива достаточно четко согласовываются с контурами поверхности соляной структуры.

Результаты выполненного моделирования отображают графические фрагменты аналоговой структурно-литологической модели, представляющие собой адекватное объемное статическое отображение внешнего и внутреннего строения соляного тела с геометризацией участков распространения определенных структурнолитологических групп соляных пород (функциональных) в объеме соляного массива (рис. 6 11).

Анализ результатов построенной крупномасштабной структурно-литологической модели позволил выполнить целевую (функциональную) оценку соляного массива. При выполнении оценки к благоприятным участкам с высокими функциональными свойствами были отнесены 1- и 2-я группы СЛТ, к неблагоприятным (или даже запрещенным) для подземного строительства - 4-я группа СЛТ. Группа СЛТ 3 представляет интерес для создания различных техногенных объектов только при наличии дополнительной защищенности в пределах участков её развития (наличию дополнительных гидравлических барьеров).

Учитывая значительное преобладание в объеме соляного массива СЛТ 3 и 4, внутренняя защищенность массива на участках отсутствия глинистых слоев-барьеров преимущественно оценивается как удовлетворительная или неудовлетворительная. Участки, благоприятные для подземного строительства, распространены в пределах массива фрагментарно. Участки для расположения эксплуатационных горизонтов с их развитием по горизонтали практически отсутствуют.

Наиболее высокие функциональные характеристики соляного массива определяются в пределах северного крыла (северо-западного сектора) соляной структуры, охарактеризованного скв. 35, которая раскрыла мощный пласт каменной соли 2-й группы СЛТ высокой соленасыщенности $(90-98 \%)$ с подчиненным количеством соляной породы 1-й группы. В пределах южного, «подвернутого» крыла, а также восточной части структуры, наиболее приближенной к зоне развития поперечного глубинного разлома, широко развиты участки с устойчиво неудовлетворительными или катастрофическими функциональными свойствами (СЛТ 3 и 4), запрещенные для техногенного вмешательства. Эти участки представлены опорными разрезами скв. 21 и 18.

Таким образом, по результатам функциональной оценки участков соляного массива установлено, что наиболее благоприятным для техногенного вмешательства является северное крыло соляной структуры (см. рис. 6), а также участки в центральной части структуры, имеющие дополнительный барьер в виде выдержанного глинистого прослоя (на глубинах около 400 м и более). Следует отметить, что по умолчанию не рассматривается для создания техногенных объектов верхняя часть соляного массива, подверженная воздействию экзогенных геологических процессов (примерно до глубины 150 м по аналогии с Солотвинским куполом).

3.2. Оценка геологических параметров, определяющих возможности целевого использования Тереблянской соляной структуры. Под геологическими параметрами подразумеваются структурно-геологические особенности месторождения, функциональные свойства и внешние условия, которые влияют во времени на защищенность создаваемого объекта, неотектонические и экзогенные процессы, а также степень прогрева геологической среды, которая определяется тепловым потоком и характеризуется геотермальным градиентом.

Геолого-промышленная оценка Тереблянского месторождения проводилась с учетом следующих геологических параметров.

1. Соляное тело приурочено к зоне пересечения двух тектонических разломов осадочной толщи, унаследованных от глубинных разломов донеогенового кристаллического фундамента, современная тектоническая активность которых не установлена. Кроме того, установлено, что пространственное положение участков каменной соли с незавершенной перекристаллизацией (с резко сниженными механическими свойствами) тяготеет к зоне разломов. Поэтому при выборе перспективных объемов приоритет сохраняется за участками, наиболее отдаленными от зоны разломов.

2. По вещественному составу, морфологии поверхности соляного тела и функциональным свойствам, определяющим возможности создания экологически обеспеченных подземных объектов (Khrushchov, 2014), резко различаются южное и северное крыло месторождения. По совокупности приведенных параметров северное крыло является более благоприятным для эксплуатации, поскольку отличается более высоким качеством каменной соли, относительно спокойным залеганием, возможностью корреляции породных слоев, меньшим объемом механически ослабленных зон, меньшим развитием зон брекчирования и лучшей степенью их последующей кристаллизации. 


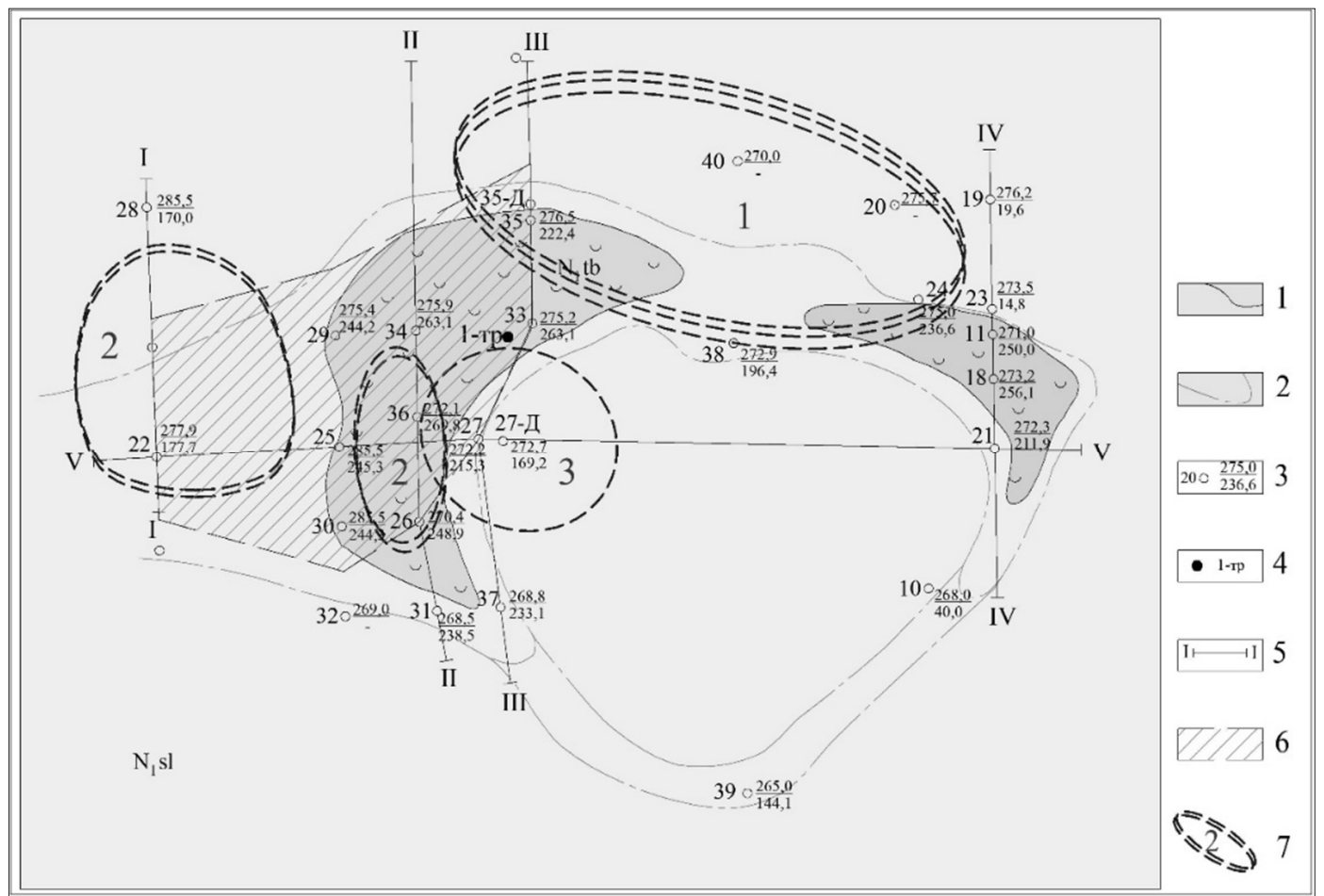

Рис. 6. Геологическая карта Тереблянской соляной структуры с выделением перспективных участков 1 - контур выхода соляной толщи под четвертичные отложения;

2 - контур соляного тела по геофизическим данным;

3 - скважины детальной разведки 1955 - 1956 годов: в числителе - абс. отм. земной поверхности, в знаменателе - абс. отм. поверхности соляного тела;

4 - сверхглубокая нефтепоисковая скважина $1-\mathrm{Tp}$;

5 - линии фрагментов структурно-литологической модели (СЛМ);

6 - площадь разрешения на пользование недрами (№ 6192, 16.03.2017 г.);

7 - перспективные участки и их ранжирование:

1) - перспективность первого ранга; наиболее благоприятный участок для всех направлений;

2) - перспективность второго ранга: участки, благоприятные для добычи соли геотехнологическим способом;

3) - перспективность третьего ранга; зафиксировано высокое промышленное качество каменной соли, прогнозируются высокие функциональные свойства, требующие подтверждения из-за противоречивости данных

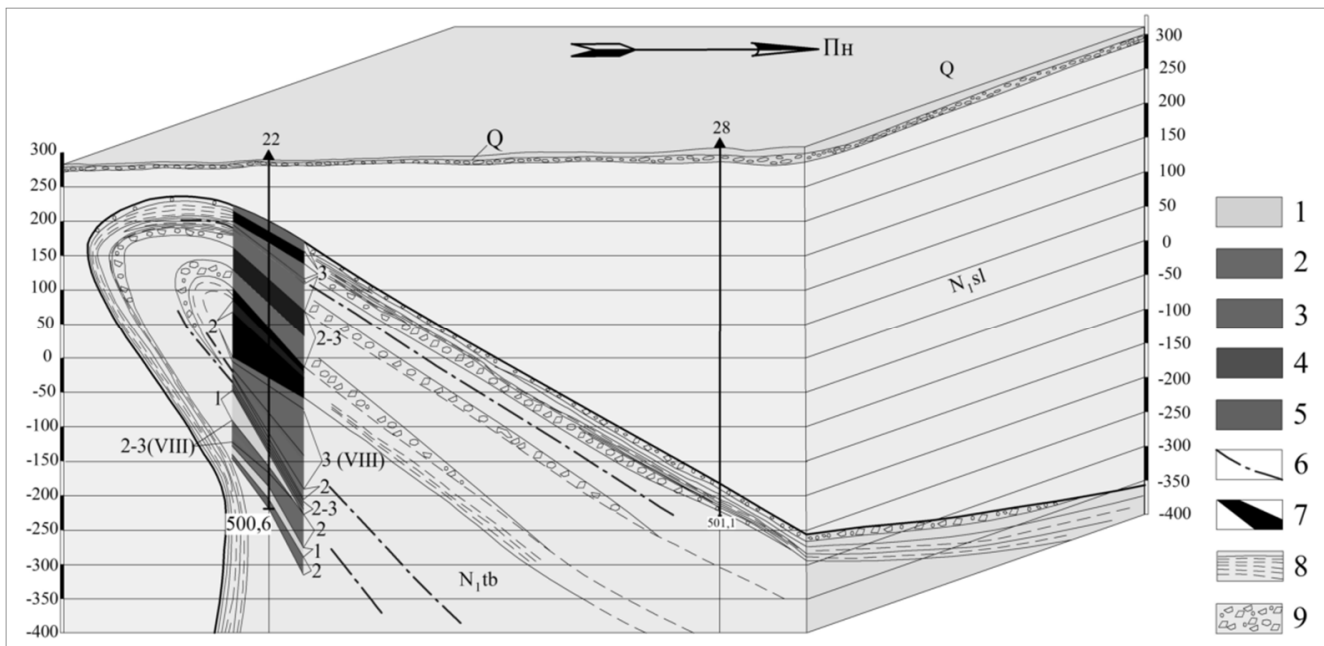

Рис. 7. Фрагмент 1 аналоговой структурно-литологической модели Тереблянского диапира по линии I - I 1 - 4 - группы структурно-литологических типов соляных пород; 5 - типичная соляная порода зоны течения (CЛT VIII); 6 - прогнозируемое развитие зон течения; 7 - фактически установленные слои несоляных пород;

8 - прогнозируемое развитие слоев несоляных пород; 9 - прогнозируемое развитие зон интенсивного брекчирования Другие условные обозначения - на рис. 4 


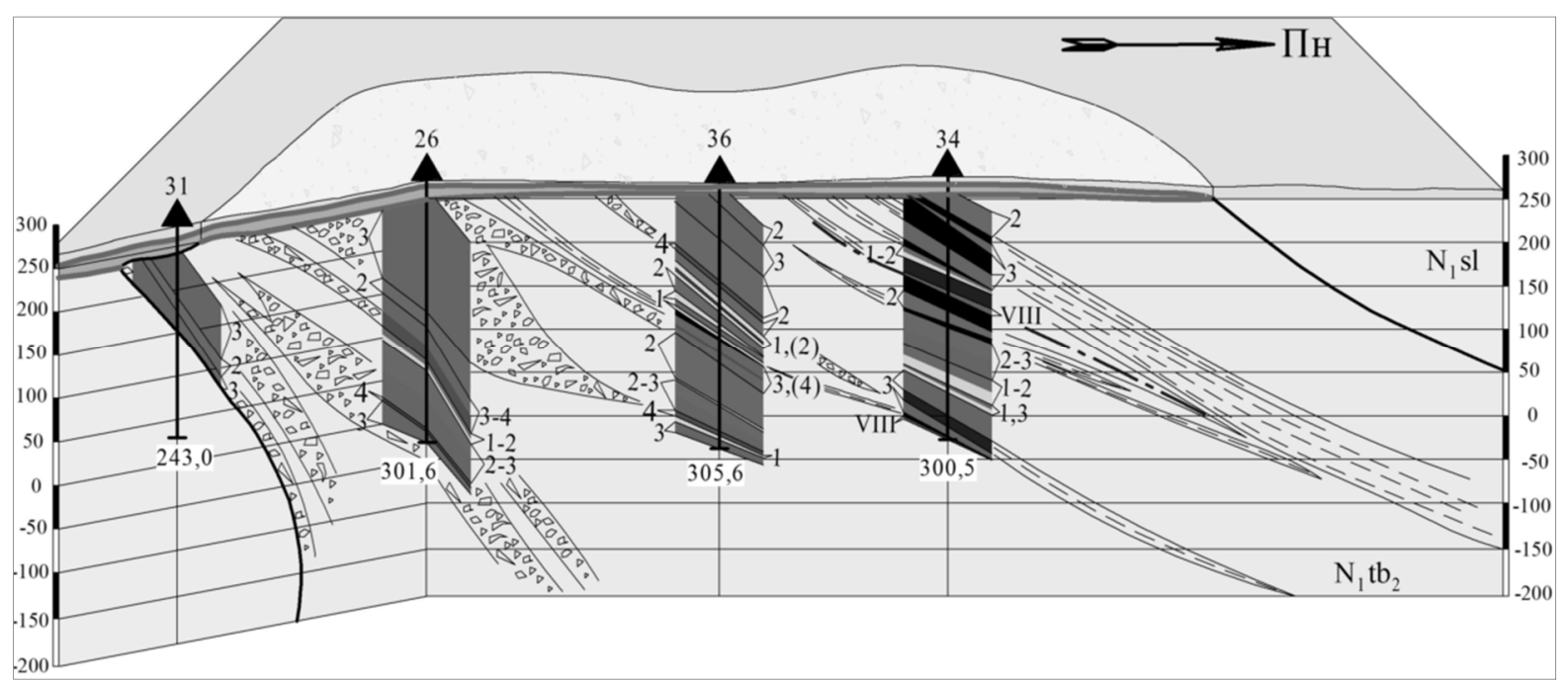

Рис. 8. Фрагмент 2 аналоговой структурно-литологической модели Тереблянского диапира по линии II - II Условные обозначения - на рис. 4 и 7 (здесь и далее)

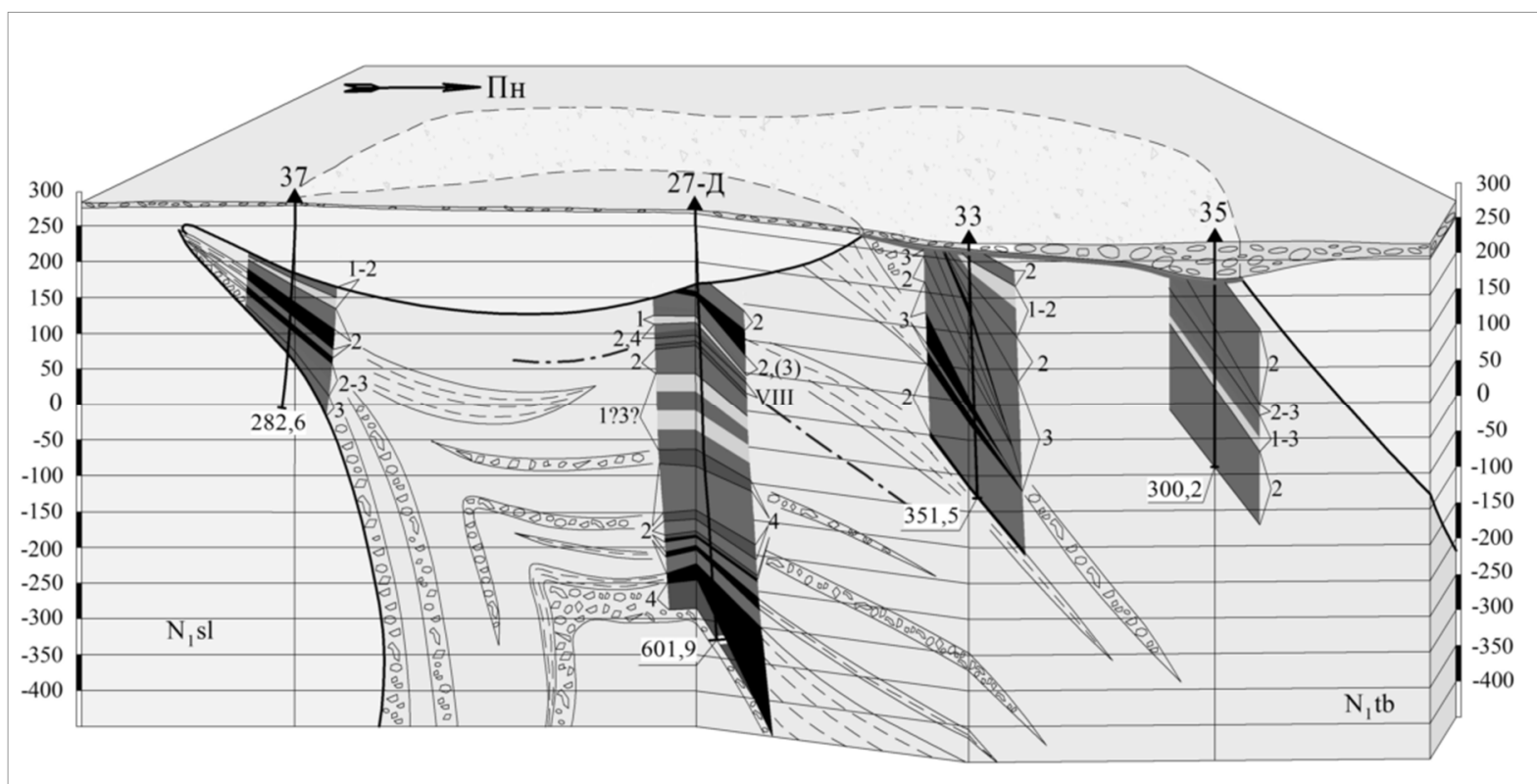

Рис. 9. Фрагмент 3 аналоговой структурно-литологической модели Тереблянского диапира по линии III - III

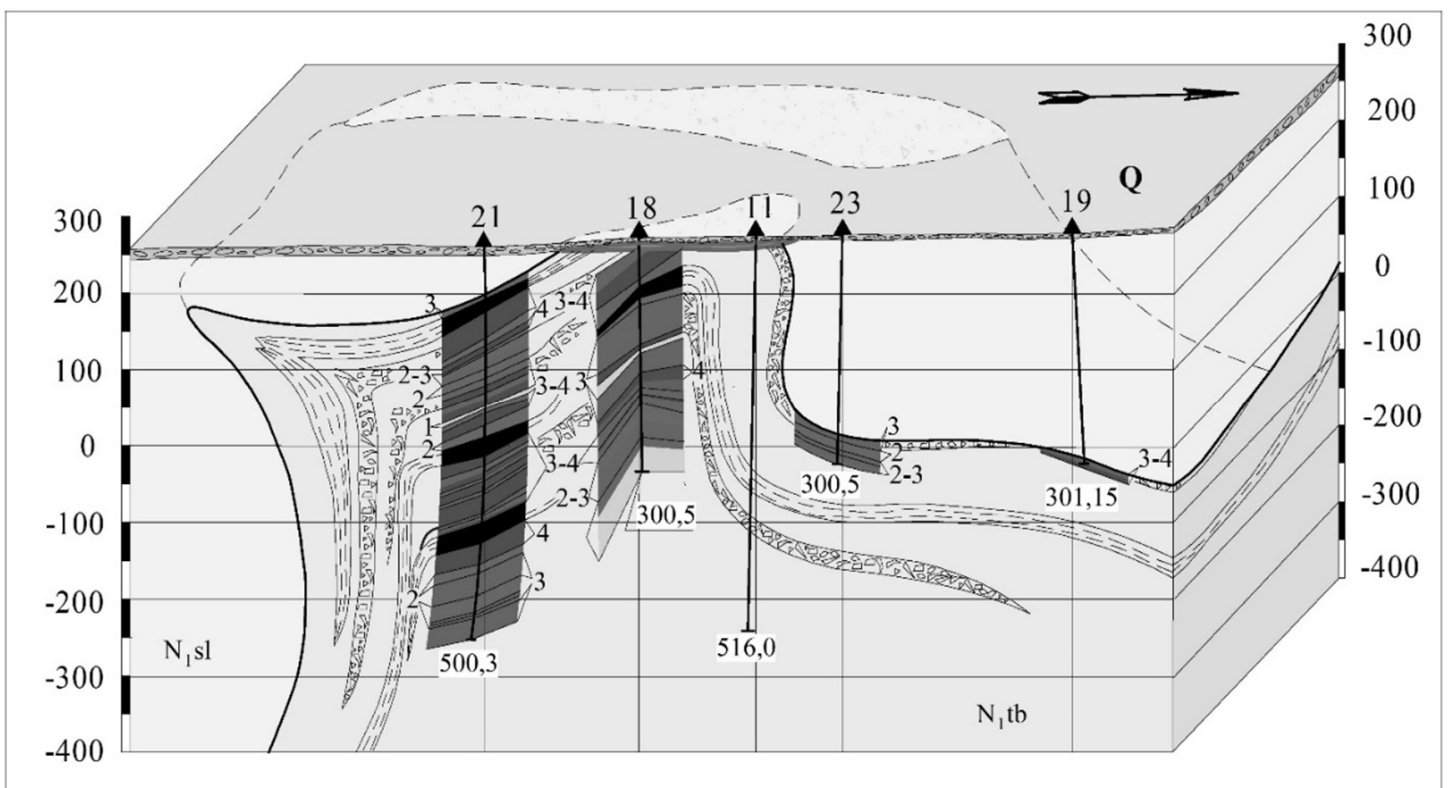

Рис. 10. Фрагмент 4 аналоговой структурно-литологической модели Тереблянского диапира по линии IV - IV 


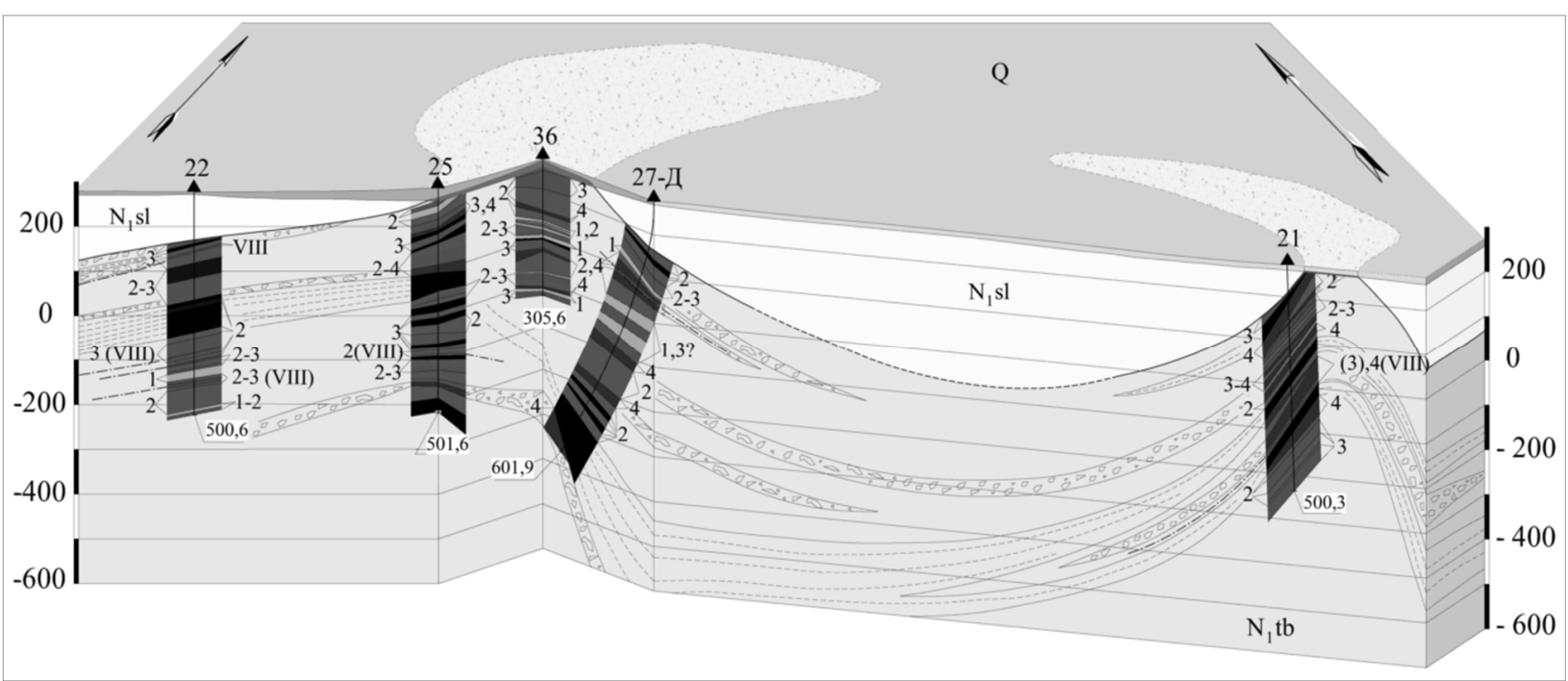

Рис. 11. Фрагмент 5 аналоговой структурно-литологической модели Тереблянского диапира по линии $\mathrm{V}-\mathrm{V}$

3. Территория месторождения (региона с незавершенной тектонической активностью) отличается наиболее высокими показателями тепловых потоков и геотермальных градиентов на всей территории Украины - $80-90 \mathrm{MBT} / \mathrm{M}^{2}$ и больше (при установленных колебаниях последнего $22-120 \mathrm{MBT} / \mathrm{M}^{2}$ ). В результате рефракции теплового поля соляным телам присущ еще более высокий геотермальный градиент, чем вмещающей их толще. Этот факт должен приниматься во внимание как особый геологический фактор при определении перспективности Тереблянской структуры, особенно при выборе участков расположения объектов, для которых важны температурные показатели в подземном пространстве (эксплуатационные горные выработки, спелеосанаторий). Территории Теребли и Солотвино находятся в одинаковых геотермальных условиях (Atlas, 2001), и это позволяет нам ожидать одинаковые геотермальные градиенты на обоих участках расположения соляных тел. Установленный геотермальный градиент для солотвинского соляного тела составляет 3,6 $4,4{ }^{\circ} \mathrm{C} / 100$ м, или в среднем $4,0{ }^{\circ} \mathrm{C} / 100$ м. Это означает, что увеличение глубины расположения подземных объектов на 100 м влечет за собой увеличение температуры в них примерно на $4^{\circ}$. Этот момент регламентирует выбор глубины расположения выработок спелеосанатория (примерно $250-300$ м) и ограничивает выбор участков отработки по глубине примерно до $500 \mathrm{M}$.

4. Достаточно условная внешняя защищенность соляного тела требует оставления верхнего водозащитного целика соляного массива минимальной мощностью 100 м (уточняется при проектировании). При этом для добычи каменной соли геотехнологическим методом рекомендуется разработку начинать с максимальных глубин в блоке подсчета запасов.

5. Участки брекчирования соляной породы Тереблянской структуры требуют особого подхода. В соответствии с фактическими данными геологических описаний скважин различные типы брекчий (соляной, соляно-глинистой и др.) составляют не менее 50 \% объема соляного массива до глубины 500 м. При детальной обработке данных было установлено, что значительная часть брекчий с преобладанием соляной составляющей (содержание $\mathrm{NaCl}$ более 60 - 70 $\%)$ представляет собой хорошо сцементированную породу брекчиевой текстуры с прогнозируемыми удовлетворительными функциональными характеристиками, на что указывает описание характера и степени сцементированности породы, а также устойчивый выход керна на уровне 96 - $100 \%$, что невозможно для структурно-литологического типа каменной соли, определенного как «соляная брекчия». В связи с этим и в соответствии с принятыми методологическими принципами поинтервальное описание разрезов скважин было переинтерпретировано: значительный объем брекчий был квалифицирован как неравномерно загрязненная прочная каменная соль брекчиевой текстуры (СЛТ 3).

3.3. Установление соответствия геологических параметров перспективных участков техническим требованиям к созданию объектов различного типа (по направлениям).

Тип создаваемых объектов в соляном массиве определяется предполагаемыми направлениями подземного строительства, среди которых с методологической точки зрения выделяются три группы сооружений: эксплуатационные выработки шахтного типа, объекты геотехнологических методов эксплуатации, создание хранилищ 
углеводородов. В качестве потенциально возможных направлений использования Тереблянской структуры рассматриваются добыча каменной соли шахтным и геотехнологическим методами, а также создание спелеотерапевтического объекта, подразумевающее строительство шахты. На данном этапе специальный вопрос о возможности создания подземных хранилищ не рассматривается в силу отсутствия актуальности. Также ввиду недостаточной внешней защищенности соляной толщи не рассматривается добыча каменной соли открытым способом как экологически небезопасная.

Технические требования к созданию выработок шахтного типа с целью эксплуатации соляных ресурсов следующие:

- принятые кондиции качества на каменную соль. Как было показано, каменная соль месторождения в основном соответствует требованиям ко II сорту соли для промышленной переработки, и только отдельные маломощные прослои - пищевой соли. Получение пищевой каменной соли не исключается, однако это возможно только при условии применения технологий обогащения на поверхностном перерабатывающем комплексе (прежде всего, очистки каменной соли от нерастворимых примесей с повышением конечного качества продукции). Следует отметить, что опыта применения технологий обогащения каменной соли в Украине нет, хотя данный вопрос неоднократно прорабатывался, в том числе для каменной соли баденской соленосной формации;

- наличие значительных запасов соляного сырья, которые отвечают принятым кондициям, для обоснования рентабельности строительства шахты;

- выдержанность по простиранию мощных слоев каменной соли, пригодных для эксплуатации шахтным способом. Наилучшее соотношение выдержанности по простиранию и качественных характеристик присуще северному крылу месторождения;

- допустимые прогнозируемые температуры шахтного воздуха, которые устанавливаются для шахтеров в соответствии с санитарными требованиями (ДСН 3.3.6.042-99), - не выше $27^{\circ}-$ $28^{\circ}$. Такие температуры ожидаются на глубинах около 430 - 450 м. На больших глубинах потребуется кондиционирование рудничного воздуха с соответствующим снижением рентабельности производства.

Технические требования для участков добычи каменной соли геотехнологическим методом с получением насыщенных рассолов выщелачивания являются наименее жесткими и сводятся к общим требованиям по расположению камер выщелачивания в пределах участков с удовлетворительными функциональными свойствами. Количество нерастворимого остатка, представленного преимущественно глинистым веществом, жестко не регламентируется, поскольку современными технологиями предусмотрено несколько этапов механической и химической очистки сырого рассола. Согласно представленным требованиям, для организации добычи соли выщелачиванием могут использоваться объемы соляного массива, представленные СЛТ 1 и 2 (3), мощностью не менее 50 м.

Дополнительные требования $\kappa$ выбору участков расположения спелеосантория связаны с необходимостью повышения безопасности объекта и учета показателя эффективности лечебного процесса. Согласно многолетнему опыту проведения спелеотерапии в условиях микроклимата солотвинских спелеосанаториев, оптимальными параметрами для обеспечения эффективного лечебного процесса являются следующие: 1) постоянная температура воздуха в диапазоне $20-25^{\circ} \mathrm{C}$; 2) постоянная влажность воздуха, составляющая не более 20 - $60 \%$ (влажность регулирует концентрацию лечебного аэрозоля в воздухе); 3) предпочтительное среднее содержание нерастворимого остатка глинистого состава в соляном массиве выбранного участка - около $5 \%$; 4) предпочтительное содержание первичной влаги в соляном массиве - 0,05 - 1,0\% (на данном этапе этот фактор не может быть принят во внимание ввиду полного отсутствия лабораторных испытаний на содержание влаги). Приведенные параметры нормативно не урегулированы, но, как установлено экспериментально, именно их сочетание определяет высокую эффективность лечения в условиях соляных шахт Закарпатья. Ожидаемые микроклиматические параметры в подземном пространстве Тереблянской структуры полностью соответствуют приведенным.

4. Перспективы использования соляной структуры и варианты инвестиционных решений. Проведенные исследования показывают, что Тереблянская соляная структура представляет наибольший интерес с точки зрения создания подземного спелеотерапевтического объекта, потребность в котором чрезвычайно велика, и добычи соли геотехнологическим методом с получением рассолов выщелачивания.

Принимая во внимание незначительные площади, которые занимают выработки спелеосанатория, а также малые параметры необходимых выработок для оборудования подземного лечебного отделения, благоприятный участок для строительства спелеосантория устанавливается в пределах северного крыла структуры (в 
районе скв. 35). Спелеосанаторий должен быть создан в интервале глубин 250 - 300 м (по температурному фактору) и только в пределах развития СЛТ 1 и 2 (по факторам защищенности и содержанию нерастворимого остатка). При этом стволы рекомендуется проходить по вмещающей толще со стороны северного крыла месторождения. Однако решение вопроса о целесообразности строительства нового подземного спелеосанатория и его пространственного размещения также необходимо координировать с решением вопроса об одновременном функционировании горнодобывающего предприятия в силу ряда причин, прежде всего, необходимости постоянного квалифицированного горногеологического и технического обслуживания объекта. Таким образом, при положительном решении о строительстве спелеосанатория необходимо предусмотреть сопутствующую добычу каменной соли в небольших объемах (около 100 тыс. т/год). При проектировании объекта сначала оконтуривается участок расположения спелеосанатория, а затем происходит планирование и проектирование шахтного поля. Для повышения безопасности объекта над выработками спелеосанатория не должно быть эксплуатационных камер.

Поскольку наиболее перспективный участок охарактеризован недостаточно, для расширения границ подсчета запасов и изучения технологических свойств каменой соли обязательно предусматривается доразведка участка путем бурения дополнительных глубоких скважин (до 600 м) за пределами сводовой части соляного тела. Основная часть скважин должна пройти вертикально по вмещающей толще, как минимум до абс. отм. $\pm 0,0$ м, при достижении соляного тела ниже этой отметки - с заданным искривлением в сторону соляного тела. Бурение необходимо проводить с отбором керна, предусматривающим полный комплекс лабораторных исследований кернового материала (химические исследования, определение прочностных и технологических свойств пород), а также термометрию скважин. Расположение стволов в пределах вмещающей толщи и соединенных с соляным массивом горизонтальными (наклонными) квершлагами является наиболее рациональным с точки зрения экологической безопасности объекта. Рекомендуемая инклинометрия скважин связана с тем, что в случае положительного решения о выборе участка для строительства шахты пройденные скважины могут быть использованы как пилотные для проходки шахтных стволов.

Для организации рассолопромысла участка добычи каменной соли методом выщелачивания - выделяются два основных благо- приятных участка, кроме вышеприведенного перспективного участка соляного массива (см. рис. 6):

1) участок, охарактеризованный скв. 22 , в интервале глубин ниже 330 м (абс. отм. -- 50 м); соленасыщенность в пределах участка составляет $84-98 \%$; защищённость участка повышена за счет наличия дополнительного внутреннего гидравлического барьера - ненарушенного мощного (56 м) плотного глинистого слоя над приведенным интервалом глубин (см. рис. 7, $11)$

2) пачка каменной соли, раскрытая скв. 26 и 36 - в интервале глубин +50 - -- 150 м; каменная соль представлена 2- и 3-й группами функциональных типов; соленасыщенность здесь варьирует в широком спектре (42 - 99,8 \%) (см. рис. 8).

В пределах структуры также привлекает внимание с точки зрения удовлетворительных функциональных свойств и высокой соленасыщенности (на уровне 95,9 - 99,9 \% $\mathrm{NaCl}$ ) еще один участок - в районе скв. 27, 27-Д, в интервале глубин 234 - 340 м, однако этот участок охарактеризован противоречивыми данными разведки. Наиболее целесообразным решением в отношении данного блока будет включение его в перспективное шахтное поле с доразведкой из горных выработок северного участка: дополнительное бурение скважин с поверхности в центральной части структуры является нерациональным, поскольку вокруг скважины необходимо будет оставлять целик диаметром до 30 м, и это приведет к потере запасов хорошего качества и увеличению экологических рисков.

Предварительно выбранный участок подлежит доразведке бурением одной (двух) скважин с поверхности с целью выполнения технологических испытаний каменной соли для добычи выщелачиванием и выбора некапиталоемкой схемы очистки рассола.

Целесообразность разработки Тереблянской структуры геотехнологическим методом очень высокая, поскольку хлоридно-натриевые рассолы выщелачивания имеют широкий спектр применения в промышленности (а также бальнеологии). Гипотетический перечень продукции, которая может быть получена при их переработке, достаточно велик, в частности: соль выварочная типа «экстра» в ассортименте (пищевая, в том числе йодированная и фторированная, для промышленной переработки), соль фармакопейной чистоты ( $\mathrm{NaCl}-99,99 \%)$, косметические и лечебные смеси, др. Кроме того, хлоридно-натриевые рассолы являются основным сырьем для получения многих видов химической продукции, наиболее востребованным из 
которых (согласно оперативно проведенным маркетинговым исследованиям) является гипохлорит натрия, $\mathrm{NaClO}$.

Варианты инвестициионных решений. Как было показано, строительство шахты только с целью добычи каменной соли II сорта для промышленной переработки без последующего обогащения представляет огромные экономические риски. Опираясь на совокупность информации об объекте, а также результаты эскизной технико-экономической оценки нового строительства и предварительных маркетинговых исследований, можно принять следующие инвестиционные решения о новом строительстве на базе использования запасов месторождения:

I - строительство шахты для размещения спелеосанатория европейского уровня и сопутствующей добычи каменной соли;

II - организация добычи каменной соли геотехнологическим способом с получением хлоридно-натриевого сырья в виде насыщенных рассолов;

III - организация комплексного объекта, включающего рассолопромысел для добычи каменной соли геотехнологическим способом и рудник с обустройством спелеосанатория и сопутствующей добычей каменной соли.

1. Планирование проведения горных работ для первого варианта должно осуществляться с учетом предварительного определения места расположения спелеосанатория с целью исключения проходки горных выработок выше подземного лечебного отделения. Планирование объемов сопутствующей добычи каменной соли необходимо начинать с проработки вариантов обогащения каменной соли для получения соли пищевого качества.

2. В случае принятия решения о добыче каменной соли только геотехнологическим способом, для расположения рассолопромысла может быть использован любой из предлагаемых участков, в том числе северный наиболее перспективный участок, однако при таком решении в дальнейшем невозможно будет вернуться к вопросу о создании спелеосанатория, поскольку для его строительства существует только один благоприятный участок. Вариант применения геотехнологического метода добычи предусматривает также строительство перерабатыва- ющего комплекса (как минимум вакуумвыварочного завода) для получения выварочной соли в ассортименте, а также некоторых видов химической продукции.

3. Создание комплексного объекта является наиболее экономически целесообразным вариантом. Этот вариант предусматривает выделение двух отдельных участков недр в соляном массиве, разделенных вертикальным охранным целиком. Наличие участка выщелачивания позволит использовать полученные насыщенные хлоридно-натриевые рассолы также в бальнеологических целях для расширения спектра медицинских услуг.

При решении о создании комплексного объекта добычи соли обоими методами самым главным требованием в соответствии с правилами охраны недр (НПАОН 00.0-1.01-85) является необходимость площадного разделения участков с разными способами добычи вертикальным барьерным целиком обоснованной мощности, но не менее 100 м (Bosevska, 2010; Raluca, 2015) с соответствующим изменением подсчета запасов по разным кондициям и правоустанавливающих документов (рис. 12).

Функционирование комплексного объекта подразумевает строительство перерабатывающего комплекса, включающего как минимум цеха переработки рассолов (вакуум-выварки) и цеха переработки каменной соли (с возможным обогащением).

Первой задачей прединвестиционной проработки вопроса является выполнение рекомендованной доразведки месторождения с получением исходных данных для проектирования (прежде всего, химических, физикомеханических (в том числе прочностных), технологических свойств соляных пород) и выбора технологии обогащения каменной соли, а также маркетинговой оценки рынков отдельных видов соляной и химической продукции, которую гипотетически возможно получить из хлориднонатриевого сырья. По самым предварительным оценкам, одними из самых востребованных видов производимой продукции могут быть соль фармакопейной чистоты и гипохлорит натрия, получаемый электролизом хлоридно-натриевых рассолов. 


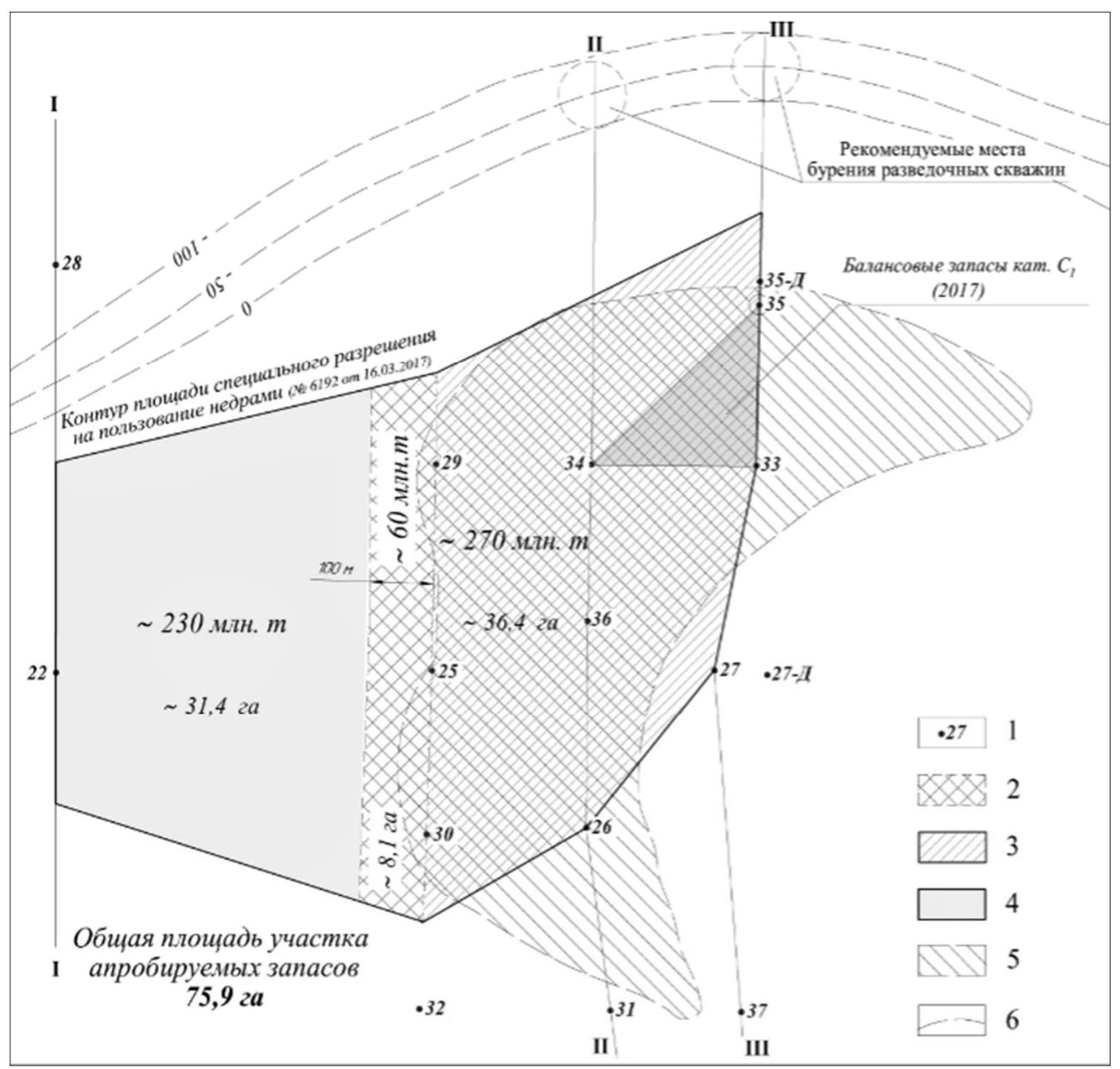

Рис. 12. Проработка варианта апробации и отработки запасов двумя методами - шахтным и геотехнологическим:

1 - скважины детальной разведки;

2 - рекомендуемое положение барьерного целика между участками недр с различным способом разработки с указанием площади и ориентировочных запасов;

3 - рекомендуемый участок для размещения шахтного поля и спелеосанатория с указанием площади и ориентировочных запасов;

4 - рекомендуемый участок добычи соли геотехнологическим методом с указанием площади и ориентировочных запасов;

5 - выход западного фрагмента соляного тела под четвертичные отложения;

6 - изолинии поверхности соляного тела (по геофизическим данным)

Выводы. Выполненная современными структурно-литологическими методами предварительная целевая геолого-промышленная оценка Тереблянской соляной структуры показала, что в целом данное соляное тело не является весьма благоприятным для создания масштабных подземных инженерных объектов, развернутых по латерали, в связи с наличием структурнолитологических типов пород, являющихся неблагоприятными для подземного строительства, при удовлетворительном уровне внешней защищенности массива. Расположение неблагоприятных участков тяготеет к зонам тектонических разломов, унаследованных от глубинных разломов кристаллического фундамента.

В то же время, в пределах структуры выявлены участки с удовлетворительными и высокими функциональными свойствами, имеющими ограниченное пространственное распростра- нение в пределах массива. Наиболее перспективным как по эколого-геологическому критерию, так и по соответствию геологических условий техническим требованиям ко всем типам объектов, является северное - северозападное крыло соляной структуры. Промышленную ценность представляют собой также участки в центральной части западного фрагмента соляной структуры, благоприятные для добычи соли методом выщелачивания. Выделенные перспективные участки находятся за пределами застроенной территории с. Теребля.

Принимая во внимание социальноэкономический аспект, наиболее рациональным способом использования соляного массива обозначено создание комплексного объекта, включающего добычу каменной соли двумя методами - геотехнологическим и шахтным, подразумевающим создание спелеосанатория, связанно- 
го с горнодобывающим объектом пространственно и технически (общими стволами). Однако для принятия окончательных инвестиционных и проектных решений необходимо доизучение соляных пород структуры с целью определения технологических и физикомеханических свойств пород соляного массива.

Несмотря на невысокое качество каменной соли Тереблянской структуры (средняя соленасыщенность - около 90\%), в настоящий момент она имеет ряд преимуществ перед альтернативным объектом, Солотвинским куполом, для возрождения соледобычи и спелеотерапии в регионе. Преимущества тереблянского варианта аргументируются несколькими факторами: отсутствием техногенной нарушенности структуры, высокими экологическими показателями территории, что является определяющим для создания лечебного объекта и производства некоторых видов солей, требовательных к состоянию среды переработки (например, фармакопейной соли), а также наличием значительных незастроенных площадей.

\section{Библиографические ссылки}

Andrieieva-Hryhorovych, A., Ponomarova, L., Prykhodko, M., Semenenko, V., 2009. Stratyhrafiia neohenovykh vidkladiv Zakarpatskoho prohynu [Stratigraphy of Neogene deposits of the Transcarpathian depression]. Geology and geochemistry of combustible minerals, 2 (147), 58 - 70 (in Ukrainian).

Atlas "Heolohiia i korysni kopalyny Ukrainy. Masshtab $1: 5000$ 000" [Geology and minerals of Ukraine], 2001. Kyiv (in Ukrainian). ISBN96602-2139-8.

Barjah, A.A., Konstantinova, S.A., Asanov, V.A., 1996. Deformirovanie soljanyh porod [Straining of rock salt]. Ekaterinburg: Mining Institute of the Ural Branch of the RAS (in Russian).

Bokun, A.N., 1981. Soljanye struktury Solotvinskoj vpadiny [Salt structures of the Solotvino depression]. Kyiv: Naukova Dumka (in Russian).

Bosevska, L.P., 2010. Osnovnye principy inzhenernogeologicheskoj ocenki soljanyh massivov, ispol'zovanie ih kak sredy dlja sooruzhenija podzemnyh ob'ektov razlichnogo naznachenija [Significant geological engineering assessment salt massifs, using them as an environment for construction of multipurpose underground objects]. Visn. Dnipropetr. Univ. Ser. Geol. Geogr., 12(18), 3/2, 37 - 46 (in Russian). doi: $10.15421 / 111018$

Bosevska, L.P., Khrushchov, D.P., Lobasov, O.P., Kyrpach, 2010. Tsyfrova model Solotvynskoi solianokupolnoi struktury [Solotvyno salt dome structure digital model]. Collection of scient.works of IGS NASU, Kyiv, Vol. 3, 248 - 255 (in Ukrainian)
Bosevska, L.P., 2013. Strukturno-litologicheskaja harakteristika soljanyh diapirov Zakarpat'ja [Structural-lithologic characteristics of the Transcarpathia salt diapirs]. Visn. Dnipropetr. Univ. Ser. Geol. Geogr., 15(21), 37 - 46 (in Russian). doi: $10.15421 / 111307$.

Bosevska, L.P., Khrushchov, D.P., 2011. Nadzvychaina ekolohichna sytuatsiia v Solotvyno: heolohichni prychyny i stratehiia rozviazannia problemy [Emergency environmental situation in Solotvyno: geological causes and strategy of problem solution]. Visn. Dnipropetr. Univ. Ser. Geol. Geogr., 13 (19), 80 - 90 (in Ukrainian). doi: $10.15421 / 111117$

Bosevska, L.P., Kyrpach, Yu.V., 2013. Celevoe strukturno-litologicheskoe modelirovanie Terebljanskogo soljanogo diapira [Target oriented structural-lithological modeling of the Tereblyanskiy salt diaper]. Proceedings of the 5th Ukrainian scientific conference of young scientists, November 19 - 20, 2013, Kyiv, Ukraine, 19 - 20. (in Russian).

Chabanovich L.B., Khrushchov, D.P., 2008. Nauchnotehnicheskie osnovy sooruzhenija i jekspluatacii podzemnyh hranilishh $\mathrm{v}$ kamennoj soli [Scientific and technical foundations of underground salt storage facilities construction and operation]. Kyiv: Varta (in Russian).

Cooper, Antony H., 2002. Halite karst geohazards (natural and man-made) in the United Kingdom. Environmental Geology, Vol. 42, is. 5, 505 - 512. doi: 10.1007/s00254-001-0512-9

Gutirrez, F., Johnson, K., Cooper, A., 2008. Evaporatekarst processes, landforms, and environmental problems. Environmental Geology, 53 (5). 935 -936 .

Hutorskoj, M.D., Teveleva E.A., Cybulja, L.A., Urban, G.J., 2010. Teplovoj potok v soljanokupol'nyh bassejnah Evrazii - sravnitel'nyj analiz [Comparative analysis of warm stream into salt domes basins of Eurasia]. Geotectonic. 4, 3-19 (in Russian).

Jeremic, M.L., 1994. Rock mechanics in salt mining. Laureutian University, Sudbury, Canada. Roterdam: Balkema. - III. ISBN 9789054101031

Khrushchov, D.P., Danishurka, N.A., 2002. Strukturnolitolohichni modeli solianokupolnykh struktur [Structural and lithological patterns of salt dome structures]. Geol. journ., no. 4, 67 - 77 (in Ukrainian).

Khrushchov, D.P., Bosevska, L.P., Kyrpach, Iu.V., Stepaniuk, O.V., 2009. Metodolohichni ta praktychni aspekty vyznachennia zakhyshchenosti solianykh tovshch [Methodological and practical aspects of salt strata protection determination]. Int. scient.-pract. conf. "Environmental security: problems and solutions" (Alushta, September, 7 - 9), Vol. I. Kharkiv: Raider, $99-$ 104 (in Ukrainian).

Khrushchov, D.P., Bosevska, L.P., Kyrpach, Yu.V., Stepanuyk, O.V., 2010. Human made intervention into salt massifs environment: mechanisms, fac- 
tors, results and ecological problems. Int. Conf. "GeoDarmstadt 2010 - Geosciences Secure the Future". Darmstadt, Germany, October 10 - 13, $305-306$.

Khrushchov, D.P., Bosevska, L.P., 2014. Environmental problems of salt mining in Ukraine. GEM NEWS, 22, $11-16$.

Khrushchov, D.P., Bosevska, L.P., Kyrpach, Yu.V., 2016. Overall geological industrial assessment of salt resources in the Carpathian region of Ukraine. Visn. Dnipropetr. Univ. Ser. Geol., geogr., is.19, Vol. 24(2), 137 - 148. doi: $10.15421 / 111642$

Looff, Karl M. \& Looff, Kurt M., 1998. Geologic Evaluation for Domal Salt Storage Projects. SMRI Spring Meeting, New Orleans, Louisiana, April $19-22,182-209$.

Nazary Moghadam, S., Mirzabozorg H., Noorzad A. \& Nazokkar K., 2012. Stability analysis of caverns excavated in heterogeneous salt formations. Indian Journal of Science and Technology, Vol. 5, 8 (August), 3128 - 3031. ISSN: 0874-6846

Raluca, F., Naş, S., Poruţiu, A., Sălăgean, T., 2015. Consideration regarding the overall stability of voids created in salt massifs following exploitation by dissolution. Agriculture - Science and Practice, 3 - 4 (95-96), 120 - 122.

Roy, H. Gabrielsen, Fort, Xavier \& Martinsen, Ole, 2008. Salt: Deformation, Trapping and Complexities. GEO ExPro. May. 56 - 58.

Shekhunova, S.B., 2001. Pro vnutrishniu budovu solianokupolnykh struktur (za litolohichnymy danymy) [About internal composition of saltdome structures (according to lithological data)]. Geol. Journal, 1, 48-54 (in Ukrainian). 